\title{
Covering the Campaign: News, Elections, and the Information Environment in Emerging Democracies
}

\author{
Jeffrey B. Arnold ${ }^{1}$, Aaron Erlich ${ }^{2}$, Danielle F. Jung ${ }^{3}$, and James D. Long ${ }^{* 4}$ \\ ${ }^{1}$ Assistant Professor, Department of Political Science, University of Washington \\ jrnold@uw. edu \\ ${ }^{2}$ Assistant Professor, Department of Political Science, McGill University \\ aaron.erlich@mcgill.ca \\ ${ }^{3}$ Assistant Professor, Department of Political Science, Emory University \\ danielle.jung@emory.edu \\ ${ }^{4}$ Assistant Professor, Department of Political Science, University of Washington \\ jdlong@uw. edu
}

June 22, 2018

\footnotetext{
${ }^{*}$ We acknowledge generous funding from the U.S. Agency for International Development (USAID) Development Innovation Ventures (AID-OAA-A-14-00004); the Harvard Academy for International and Area Studies [Long]; the Center for Statistics and the Social Sciences (CSSS), University of Washington [Arnold]; and McGill University [Erlich]. We thank John Beieiler, Adi Eyal and Code4SA, Wes Day, Jonathan Homola, Maura O'Neill, Phil Schrodt, Walter Mebane, and seminar participants at the University of Washington's Forum on Political Economy and Economics, the Centre for the Study of Democratic Citizenship's (CSDC) Speaker Series, and DevLab USAID for comments. Ryan Sampana, Stephen Winkler, and Wesley Zudeima provided excellent research assistance. All mistakes remain with the authors and any opinions, findings, and conclusions or recommendations expressed in this paper are those of the authors and do not necessarily reflect the views of USAID.
} 


\begin{abstract}
Scholars debate whether and how campaigns influence political behavior and electoral outcomes. No consistent theoretical framework, however, defines, measures, and analyzes electionrelated content from within the media's coverage, particularly in emerging democracies. We apply machine learning techniques on texts from nearly 100,000 news articles during South Africa's 2014 election, and use a theoretically-informed classification of election coverage to demonstrate how the conceptual scope of elections shapes voters' campaign information environment. Our results produce distinct representations of political actors and institutions during elections: a narrow classification provides heuristics cuing race, party, and incumbent performance; a broad definition reflects policy and service concerns parties debated. Topic models and word vectors show that campaign content clusters with parties and their associations with government performance and policies, but candidates vary in how much distinct coverage they obtain on valence issues. We provide methods and evidence to replicably study electoral news coverage across developing countries.
\end{abstract}




\section{Introduction}

Many factors influence individuals' voting behavior by altering the degree to which they gain and process information about an election, including knowledge of the candidates, the past performance of parties, and the credibility of politicians' promises. Lacking complete and reliable information about candidates' previous or future behavior, voters use heuristics to assist their evaluative and decision-making processes (Downs, 1957; Lupia and McCubbins, 1998). Anticipating this, politicians employ numerous strategies to shape the information environment to win citizens' support, including leveraging news coverage of the campaign (Popkin, 1994). But voters in emerging democracies face numerous individual and institutional hurdles to obtaining and digesting information about electoral actors and processes (Norris, 2014), suggesting, at best, a tenuous role for campaigns in explaining electoral outcomes (Besley, 2005). What does the information environment actually tell voters, when does it tell them, and in what ways? Further, what do the answers to these questions suggest about the nature of campaigns and electoral competition in new democracies?

We investigate the information environment reflected in news-reporting on political actors, institutions, and events in emerging democracies' elections. Three hurdles have challenged a full accounting of the contours of these countries' campaign information environment (CIE). First, politicians strategically deploy a multiplicity of cues depending on context and audience. Second, voters may not automatically or easily process media coverage: it is not obvious when voters start paying attention to the campaign, political stories may not reflect issues salient to voters, and content of news on political actors during an election period may differ from non-election periods. These conditions may create conflict or confusing information signals. Third, a lack of data on and methods to consistently analyze the range of political stories during elections has prevented system-

atic, reliable, and replicable investigation of the CIE. Even as media consumption and coverage of politics has grown significantly in the developing world, we lack a basic understanding of whether and what kind of news generates the CIE. 
To confront these challenges, we offer a new conceptual framework, data, and machine learning techniques to examine information in campaign news from approximately 100,000 stories during South Africa's 2014 election. Characterizing the CIE depends on voters' level of engagement. Building on prior studies, we characterize two types of voters that reside at opposite ends of a unidimensional continuum. At one end, information-seeking voters lack the ability to obtain (or simply discount) most electoral content during the campaign. These voters' will rely heavily on cognitive short-cuts that do not require significant engagement or updating, but rather cue "fundamentals" of an election, like appeals to ethnic (Chandra, 2004; Posner, 2005) and partisan loyalty (Stokes, 2005); or signals of party/government dominance (Blaydes, 2011; Magaloni, 2006). At the other end, engaged voters actively seek information beyond the fundamentals and gain "substantive" coverage regarding politicians' performance and position on the issues. These voters rely on heuristics that signal consequential and situational (election-specific) information to update prior beliefs and assess politicians' records and policy promises (Bratton et al., 2005). Regardless of where a voter falls along the continuum, none has complete knowledge of all election-relevant information; however, accounting for aspects of a voter's engagement helps to locate them and begin to unpack campaign coverage.

Extending these insights, we evaluate the substantive nature of the CIE by developing two theoretically grounded classifications of measuring election coverage — narrow and broad. We argue that how one defines "election-related" media coverage at the outset importantly shapes the CIE. Most obviously, elections can be thought of as the day voters cast ballots. Therefore, what we term "narrow" election-related coverage conveys only basic information about, and heuristics associated with, the identities of electoral actors and administrative procedures related to voting. Beyond that, voters who seek significantly more information about the election consume increasingly "broad" news regarding political actors and institutions, which conveys information regardless of whether stories specifically cue the election. Any coverage of politics during a campaign can be considered broad, particularly if standard political coverage generates election-specific signals that resonate with voters and influence their information-processing about their electoral choices. 
Our approach argues that labeling election coverage "narrow" or "broad" shapes both the frequency of news reports and substantive content in ways that present voters with different levels and types of information. Although actual political events during a campaign are not altered by definitions of election-related news, simply changing the scope of inquiry of election coverage leads to potentially radically different substantive representations of the CIE, representing different types of information-seeking "voters" and whether they consume a "narow" or "broad" campaign diet.

Accounting for election-related content is not the only factor likely to shape voters' engagement; we argue that the degree and nature of how political actors and events are covered in the news also reveals important dynamics of the CIE. Media stories during an election will reflect politicians' explicit messaging - appeals conveyed in speeches, interviews, and manifestos - along with coverage beyond what politicians desire - like reporting on a bad economy or corruption scandals. We therefore examine coverage of political actors and events to understand the qualitative dimensions of the CIE. We argue that if election-related news coverage provides a meaningful CIE diet, campaign content will "cluster" around certain topics, issues, or information "sets" following institutional and situational factors associated with relevant political actors. These information sets will vary by actor in ways demonstrating the explicit and implicit signals that drive or inhibit their electoral appeal by offering heuristics (e.g., ethnicity, performance, policy alternatives) that inform voters' (whether narrowly or broadly engaged) choices.

Whether and how content clusters suggests important implications for how we characterize the CIE for voters at different ends of the information continuum. If information-sets cluster, even from a "narrow" definition of election-related news, we hypothesize that voters will receive exposure to diverse types of information beyond heuristics that cue social and political fundamentals. This content no doubt grows as voters expand their diet to broad consumption. However, if informationsets do not cluster around the institutional and situational features of relevant electoral actors, the CIE is unlikely to provide voters with clear signals to help them update or assess candidate quality either narrowly or broadly. More engagement with campaign news risks voters' receiving noisy, 
inconsistent, or irrelevant information that possibly cloud judgments.

We match our theoretical priors about what constitutes election-related coverage with the actual news stories in South Africa, an important case that has many features of a consolidating setting and allows us to hold country-level factors constant - the electoral system and media environment — that also inform the CIE. Similar to many other new democracies, standard assumptions about elections in South Africa point to voters' reliance overwhelmingly on racial and party heuristics given the demographic and institutional nature of political competition (Ferree, 2011). Since the end of apartheid, the African National Congress (ANC) has remained electorally dominant and, backed by most of the country's $80 \%$ black voting base, held a majority of seats in parliament in every national election since 1994. Because elections appear as foregone conclusions, many observers question whether campaign media coverage actually reveals anything important in the CIE for understanding political behavior. Yet campaigns receive wide attention in the news and opposition parties typically gain traction by campaigning against the ANC's institutional advantages and performance record — including in 2014 corruption allegations against president Jacob Zuma — and by making ideological appeals or policy promises. South Africa also provides an unusually rich data environment to apply machine learning techniques to campaign coverage, ${ }^{1}$ and most newspapers are free and digitally available. ${ }^{2}$

To evaluate how variation in our conceptions of election coverage generate variation in the CIE, we classify all articles in the corpus as "not election relevant," or electorally "narrow" or "broad" using supervised learning with a labelled subset of articles. Concurrent to our supervised learning classification, we summarize the overall news coverage with topic models. Regressing the labeled articles on these topics, we describe the news content most predictive of election-relatedness and estimate the topical composition of the articles in the election-related categories for narrow

\footnotetext{
${ }^{1}$ South Africans are heavy consumers of media (see Appendix A), outpacing other developing countries with lower incomes and less media access. But South Africa also represents where much of the developing world, including in sub-Saharan Africa, will be in the coming years given the rapid expansion of ICT globally.

${ }^{2}$ We collected a corpus of almost 100,000 news articles from over 100 publications. In contrast, many previous studies pre-select stories they believe contain election coverage in order to examine campaign events, or use selfreported media attentiveness from survey data (Banducci and Karp, 2003).
} 
and broad classifications. ${ }^{3}$ We perform word vector analysis of the content of topics clustered by relevant political actors to better account for the information-sets most associated with parties and candidates in both narrow and broad classifications.

Previewing results, defining election-related material "narrowly" or "broadly" creates variation in the CIE. First, both narrow and broad coverage provided voters election content well in advance of the election day, but political coverage dramatically intensified only two weeks before the election. Second, a narrow definition generates election coverage focused on the main candidates and parties, providing voters with heuristics associated with the racial identities of candidates, party reputations, and ANC dominance. Narrow content also went beyond the fundamentals to include coverage of issues related specifically to ANC performance and Zuma's re-election in positive and negative ways. Only one of the main challengers, Julius Malema of the Economic Freedom Fighters (EFF), managed to distinguish itself in narrow coverage (running on an economically populist message); the largest opposition Democratic Alliance (DA) and leader Helen Zille failed to distinguish themselves from coverage of the ANC, suggesting that they gained the most traction through excoriations against the government and Zuma. Third, a broad definition significantly expands coverage reflective of numerous salient policy issues advocated by the ANC and opposition — related to poverty and unemployment; service delivery (education, electricity, health care); and workers' rights. In broad coverage, these topics are less directly linked to specific mentions of candidates and parties; this coverage would therefore likely gain election salience if voters attribute policy stances and valence issues with the government or parties advocating for policy improvements.

Next, results show topic models and word vectors associated with relevant political actors cluster in ways suggestive of their relative strengths and weaknesses related to performance and valence issues. Word associations cluster around the institutional and situational features of relevant electoral actors that demonstrate the CIE provides voters with clear signals to assess candidate quality

\footnotetext{
${ }^{3}$ Our method somewhat parallels studies that use media coverage of reported events like political violence (Bagozzi and Schrodt, 2012; Schrodt, 2012); however, we focus our techniques in one country and on political coverage of elections.
} 
narrowly and these signals grow in richness and only slight noise as coverage broadens. The cooccurrence of words associated with the ANC and DA suggests that the main opposition party failed to distinguish itself from information related to the incumbent party; instead, for both parties, the ANC appears as the campaign focal point. The DA and EFF enjoyed coverage more directly related to negative ANC coverage focusing on performance, Zuma's corruption, and the economy; but the EFF also signaled its own messaging on issues distinct from the other parties. Party mentions frequently co-occur alongside mentions of policy aspects, suggesting that voters are unlikely consuming candidate or party heuristics in the absence of substantive information on valence issues. But word associations also co-occur with all of the parties on some valence issues (inequality, unemployment) such that parties did not always distinguish themselves on critical campaign themes. This pattern changes, however, closer to election day when the ANC began to dominate coverage compared to the DA and EFF on salient topics, and with certain words where the DA and EFF managed to draw a few distinctions from the ANC on specific policy focuses they advocated in the campaign.

Importantly, our findings follow from the theoretical assumptions driving our methodological choices and the assumption that measuring media coverage of politics is not epiphenomenal to the actual substance of a campaign. We believe the CIE provides an important window into salient dynamics of political competition and information available to voters because candidates understand that news reports of campaign rallies, statements, and other events will reflect the appeals they make at those events, and because candidates cannot completely control whether and how they are covered in the news. Accordingly, our results characterize a richer and more dynamic CIE compared to many prior studies.

Two important caveats are in order. First, we do not aim to observe or account for all politicians' strategies to woo voters. Beyond media, candidates have other means to reach voters and shape the information environment — including through direct party contact (Stokes et al., 2013) — which we do not capture. But because face-to-face contact of voters is logistically difficult and costly in developing countries (Ferree and Long, 2016), we contend media coverage is at least partially 
reflective of politicians' strategies to win support and therefore reflective of voters' information sources, complementing new studies highlighting the importance of politicians' growing use of media in election campaigns in emerging democracies (Conroy-Krutz and Moehler, 2016; Horowitz and Long, 2016). Additional survey data from South Africa indicates that party contact is a complement, not substitute, to news consumption (Appendix A). Second, it is beyond our scope to measure the direct impact of any one information signal (or its relative effects) that we uncover in the CIE on individuals' electoral behavior. Instead, our analysis of news coverage provides, at least in part, the type and concentration of heuristics that likely account for the full range of information content in CIE. We believe our study therefore also compliments an emerging literature that focuses on the relative salience of information signals on political behavior in developing democracies (e.g., Adida, 2015; Carlson, 2015).

Our findings offer important theoretical and methodological implications for understanding the CIE in emerging democracies' elections. We first lend insights to debates over the role of campaigns (Bleck and van de Walle, 2013). Similar to other emerging democracies where election outcomes appear to be foregone conclusions given the salience of social identity (Horowitz, 1985), or features of consolidating institutions like restrictions to competition (Levitsky and Way, 2010), South Africa represents the standard view that campaigns are unlikely to be important because social and institutional factors constrain voters' engagement, information-processing, and electoral choices. Previous studies also point to parties' agreement on valence issues and lack of ideological divergence as further evidence downplaying the role of CIE. Our results partially accord with these views by showing that social and political fundamentals inherent in South African elections are no doubt heavily reinforced in the CIE. For the most part, racial and partisan cues redound to the ANC's benefit; in line with Ferree (2011), South African parties also appear to align on some valence issues. Our results therefore accord with the well-established correlation between race, party, and voting behavior in South Africa (Mattes and Piombo, 2001), similar to studies that document the persistent relationship between ethnicity, institutions, and electoral outcomes in emerging democracies (Chandra, 2004; Posner, 2005). 
However, our results also suggest a potentially important role for campaigns that moves beyond a CIE fixated on ethnic or party fundamentals. Our findings inspire a re-examination of the CIE and many standard assumptions made about elections. Whether and how campaigns are covered by the media is not just a question of whether campaigns "matter," but also for whom they matter and in what ways. Even if factors like ethnicity and parties are "fixed" this does not mean that voters are also necessarily "fixed." Instead, we show that variation in the degree to which voters seek information generates variation in their information environment. Even where election outcomes appear as foregone conclusions, narrow consumption of news provides voters with heuristics beyond the fundamentals, including information about performance and policy issues. While parties often agree on valence issues, this may obscure more subtle ways that parties succeed (or fail) at distinguishing their messaging: parties with more explicitly ideological commitments, like the EFF, are associated with related policy content in ways that less ideologically oriented parties, like the DA, are not. Insofar as media reveals important political dynamics relevant to political behavior, elections are not "hollow rituals" according to what the CIE reveals. Voters may consume more, and more diverse, information content that informs their voting behavior.

Methodologically, we approach the topic of campaigns and elections using both supervised and unsupervised machine learning to gain insight into what constitutes election and campaign coverage, lending insights and broad application to machine learning and research addressing problems of classification and prediction (Alvarez, 2015; Ruths and Pfeffer, 2014). Echoing extant concerns expressed about measurement in the social sciences regarding core concepts like democracy (Coppedge et al., 2011; Munck and Verkuilen, 2002) and election quality (Kelley, 2012), we contribute to recent machine learning studies of democratic politics, including election outcomes (Mebane et al., 2017), voting behavior (Nickerson and Rogers, 2014), media stories (Bagozzi and Schrodt, 2012; Beieler, 2016), and politicians' statements and legislative text (Proksch and Slapin, 2010; Spirling, 2015; Wilkerson et al., 2015). Elections form a relatively hard class of events to classify given a large number of news sources and relevant stories (even in a single election) and the potential for multiple assumptions about what constitutes the CIE based on different assumptions about voter 
engagement. By offering a theoretically-informed discussion and replicable procedure to create and analyze datasets of political events in a developing democracy, we highlight how machine learning often requires an early, consequential, and theoretically-informed attention to a part of the research design that many social scientists often take for granted because they follow (what they assume are) agreed upon ontologies of events and phenomena. Because decisions about how to delimit election-related content affects the extent and nature of the CIE in substantive ways, the difference in our narrow and broad results may indicate that views on the role of campaigns may suffer not only (or as much) from a difference in theoretical orientation as from confirmation bias.

\section{Theoretical Motivation}

Prior approaches to understanding political behavior in emerging democracies' election present two contrasting characterizations of voters' CIE that implicitly or explicitly make different assumptions about voters' access to, and engagement with, information relevant to their electoral behavior.

A first approach argues that voters lack or discount information beyond heuristics that directly cue the "fundamental" social and political dynamics that shape electoral competition, including coethnic voting, partisanship, and government/parties' coercive capacity. Information-seeking voters in these contexts only obtain or place importance on information related to ethnic and party labels (Chandra, 2004; Dickson and Scheve, 2006), and a reliance on these heuristics grows when voters do not obtain quality information regarding other aspects from which to judge candidates, like performance or policy outcomes (Posner, 2005). If institutions stay constant, these insights suggest a fairly static CIE as politicians will do little more than cue factors that reinforce voters' prior beliefs about the fundamentals of the election and play to the base since voters are unlikely to learn or update. The timing of the election is also unlikely to affect political coverage since relevant political actors are stable and voters are unlikely to update government or party evaluations. 
A second approach asserts that despite incipient democratic institutions, voters in transitioning countries rely on information beyond ethnic and party cues (Bratton et al., 2005), specifically related to the quality of candidates and the promises they make (Lindberg and Morrison, 2008). Such information relates to more situational dynamics, including incumbent performance (Bratton and Kimenyi, 2008), candidates' policy promises (Barkan, 1976), and debates about salient campaign issues (Gibson et al., 2014). These insights point to a fairly dynamic CIE, where politicians will debate issues and propose policy alternatives as a part of their campaign activities. Because government performance and policy promises are circumstantial and election-specific, appeals on these fronts require more engagement and updating from voters (compared to stable ethnic or party heuristics), and the timing of the race should matter as candidates work closer to election day to burnish their reputations.

From either perspective, information-seeking voters are no doubt exposed to information cues if they consume news about an election. But these approaches fundamentally disagree about what voters know, when they know it, and if this matters. While neither approach necessarily precludes the possibility of a range of cues beyond what voters intentionally rely on, they formulate very different predictions about the existence, nature, and relevance of different heuristics likely consumed by voters in the CIE. If fundamentals like ethnic demography, party identification, or party dominance rigidly determine electoral outcomes, media will reinforce prior beliefs on ethnic affiliation or party labels, and not provide voters with new or additional information. If, however, voters consume campaign content beyond what signals the fundamentals, the media environment can provide important information about candidates' debates on issues regarding government performance and policy adoption that may reinforce, counter, or otherwise affect learning and updating. Campaign coverage in the media therefore plays an important role reinforcing and shaping the CIE, and the importance of campaigns grows as a function of whether and how voters engage news about the election. 


\section{The Campaign Information Environment in Emerging Democracies}

Building on these different assumptions regarding voters' engagement, we develop a conceptual framework for understanding how characterizations of election-related content in the news shapes the extent and quality of voters' CIE. Rather than focus specifically on tackling this from the perspective of voters, however, we depart from previous scholarship and instead characterize the CIE through actual media coverage. At the outset, we remain agnostic as to how voters and politicians (and scholars) might say they view campaigns and elections. Instead, we contend that first thinking through how an election is defined and measured is central to characterizing the nature of the CIE. Doing so outlines the theoretical parameters to understand whether and how coverage of political events during an election shapes the CIE. From this, we can gain empirical traction indicative of what information the CIE relays to voters and possibly reveals about the salience and nature of campaigns and political competition in emerging democracies.

What is an election? Most obviously, an election is the process by which voters cast ballots that are aggregated to produce winners for elected office. Media coverage of an "election" would therefore constitute any stories that mention electoral actors or processes specifically, such as referencing candidates contesting office, voting procedures, or results declarations. Less obviously, but fundamental to understanding the CIE, an "election" could also constitute any information about political actors or institutions that play a role influencing voters' information-processing and decision-making before, on, or after election day. If media coverage of a campaign possibly includes the totality of any information about politics as consumed during an election period, what constitutes "election-related" news stories quickly complicates any obvious portrayals of the CIE. Coverage of politics in the news does not always easily, clearly, or consistently delineate electionrelated material. This no doubt varies by context, timing, election, and voter. If the CIE sometimes specifically references candidates or vote processes, but at others just covers politics more generally, 
what information do voters have to make their electoral decisions given their level of engagement and CIE diet?

We first argue that variation in definitions of "election-related" content matters critically to understanding the CIE by advancing two theoretically grounded classifications of election coverage based on a latent continuous information continuum. At one end falls "narrow" coverage, or election stories about political actors and institutions directly relevant to the decisions voters must make on election day, including stories that specifically cue electoral actors (parties, candidates) and institutions (election commissions), or mention the voting process (registration, election day). Applied to understanding the role of social and institutional dynamics that are salient to electoral behavior and outcomes in emerging democracies, our narrow definition reliably provides voters relevant heuristics that cue such fundamentals, like a candidate's ethnicity and party label, through reports mentioning candidate names or parties contesting office. If voters consume only narrow content, politicians have incentives to make appeals through obvious and clear signals in their messaging that cue the fundamentals, reinforce priors, and do not require additional updating.

At the other end of the continuum falls "broad" election-related content. Broad coverage subsumes narrow coverage, but moves further along the information continuum. Broad stories relate to political actors and institutions during the election period regardless of whether the election is specifically mentioned. ${ }^{4}$ Stories regarding politicians, government actors, and public agencies that constitute coverage of politics, but are not directly related to the election process, qualify as broad. Even though political coverage may not directly present citizens with election-related information, our concept of broad coverage is grounded in the idea that when voters consume political content during an election period, such content may gain electoral salience because voters associate distributional and policy outcomes with governmental performance. For example, coverage of the police does not directly present citizens with election-related content because the police do not contest elections. But information about the crime rate or police effectiveness may influence

\footnotetext{
${ }^{4}$ As we explain below, we consider content that does not mention politics at all "not election-related," which extends beyond our broad classification and falls outside of our theoretical scope and empirical tests.
} 
voters' evaluations of their electoral choices if they consume that information during the campaign period and attribute management of the police to elected officials. If voters consume broad content, anything related to politics near an election is considered election-related, including stories that carry politicians' explicit appeals but also other substantive content that voters attribute to elected representatives.

We therefore argue that defining election coverage "narrowly" or "broadly" shapes both the frequency of news reports and substantive content in ways that present voters with different levels and types of information reflective of variation in heuristics at either end of the continuum. The first testable implication of how our framework affects the CIE suggests that variation in a narrow or broad approach generates differences between types of campaign coverage and campaign coverage as a proportion of total news coverage. If coverage of the election is narrow, we expect voters to receive easily accessible heuristics, like ethnic or party cues, that require the least additional information; as coverage broadens, voters will be exposed to increasingly complex cues that require more information (e.g., government performance, policy), learning, and updating. Crucially, we do not argue broad coverage means everything in the CIE matters to voters; individuals will lend differential attention to various information sources. Broad coverage also does not mean that voters are necessarily better at making elector choices since it could result in coverage that produces confusing, conflict, and noisy content. But whether narrow or broad, we argue that different theoretical priors on what constitutes an "election" and election-related coverage in the news matters critically to measuring the form and content of the CIE.

Moverover, variation in the existence of information associated with relevant political actors and institutions is not the only factor likely to shape voters' engagement. We argue second that the degree and nature of how political actors and events are covered in the news also reveals important dynamics of the CIE. Regardless of where a voter finds themselves on an information continuum, news stories do not provide consumers electoral cues in a vacuum. If news coverage provides a meaningful CIE diet, campaign content will "cluster" around certain topics, issues, or information 
"sets" following institutional and situational factors associated with political actors and government agencies. These sets likely vary by actor or institution in ways that demonstrate explicit and implicit cues that drive or inhibit their electoral appeal. A party that draws support from a certain ethnic group will be associated with ethnically-related content like appeals to identity or group loyalty (and potentially in a local language). Parties associated with economic platforms will enjoy information clusters related to the state of the economy or economic policies; parties making ideological appeals will have their names associated with attendant policy promises; incumbent parties will cluster on content related to government performance topics like service delivery, corruption, or the economy; and opposition parties will be associated with messaging on government failures and alternative policy direction. If information-sets do not cluster around institutional and situational features of relevant electoral actors, the CIE is then unlikely to provide voters with clear signals to help them update or assess candidate quality either narrowly or broadly; instead, more engagement with campaign news risks voters' receiving noisy, inconsistent, or irrelevant information that may cloud decision-making.

The nature of whether and how content clusters in information sets suggests a second set of testable implications for how we characterize the CIE for voters at different ends of the information continuum. If the content and form of appeals varies by characteristics of the parties and what voters perceive of them, even from narrow election-related news, information-seeking voters will be exposed to more diverse types of information than simply heuristics cuing social and political fundamentals. Simply by consuming campaign news, voters will receive information related to performance, policy, and valence issues, and these factors grow as voters expand engagement. Within narrow and broad categories, we may also observe changes over the course of the campaign as politicians compete more intensely closer to the election and as voters pay more attention. 


\section{Setting}

We situate our study in comparative analysis by contextualizing the factors that contribute to South African campaigns and voters' CIE. Its electoral system and media environment means campaigns are truly "national," therefore, studying local and national news of the election reveals important dynamics to the race.

First, the country forms a single nation-wide legislative constituency that elects 400 members to its National Assembly (parliament). Voters cast a single ballot for a party; seats are apportioned proportionally to parties based on vote share. Parties determine candidate rankings for their lists, and the leader of the majority party forms the government (title "president" is equivalent to "prime minister"). While voters typically have knowledge of top party leaders and government officials who are likely to gain seats, they have considerably less knowledge of individuals further down party lists (Reynolds and Reilly, 1997). This system creates powerful incentives for politicians to build strong parties and move up the ranking, perhaps at the expense of building strong personal linkages with constituents (Mattes and Southall, 2004; Reynolds, 1999). Politicians therefore rely on party mobilization, and news coverage of party activities, to mobilize support (Lodge, 2004).

Second, the media landscape provides significant potential campaign exposure. South Africa has a high literacy rate (95\% of over-15s, and $93 \%$ of women) and a long history of accessible national and local newspapers. The government does not own or limit the publication of stories by the main media houses. ${ }^{5}$ ICT has also grown rapidly in South Africa in the last decade (Appendix H). The horse-race, political rallies, scandals, strikes, and the state of public services all receive coverage near elections. Appendix A analyzes the citizens' media consumption using Afrobarometer data. Large proportions of South Africans receive news specifically from newspapers, either every day (27\%) or a few times a week $(24 \%)$ or month $(16 \%)$, patterns that generally hold across socio-demographic categories.

\footnotetext{
${ }^{5}$ The one exception is the South African Broadcasting Corporation; a state broadcaster on television and radio (but not newsprint). SABC coverage is seen as generally free from government influence or bias.
} 
Given its electoral rules and robust media environment, what information cues are likely to be embedded in the media's coverage of political actors and institutions near an election? While South Africa has many strong democratic institutions, they are shadowed by apartheid's legacy and racial divisions, which generate views from many observers that are largely skeptical of the role of campaigns. The institutional and racial environment perennially point to ANC dominance backed by a majority black vote. Black voters comprise about $80 \%$ of the electorate and, since 1994, the ANC has continually won national contests by wide margins. Because of the well-established correlation between race and party support, the campaign dynamics for the ANC revolve around turning out their base through appeals to predominantly black voters (Southall, 2014a). Facing ANC dominance, other parties have difficulty winning at the national level, including the largest opposition Democratic Alliance (DA), which draws support primarily from white and "coloured" (mixed-race) voters in urban areas and Western Cape. Some party labels also contain heuristics that guide voters' evaluations of party credentials: the ANC has a pro-black reputation and the DA is seen as a primarily white party (Ferree, 2011).

Yet the electoral advantages enjoyed by the ANC do not mean that campaigns lack policy substance. The ANC often promotes "bread and butter" issues (Habib and Sanusha, 2006) to touts its success at promoting economic stability and growth since apartheid. But many blacks feel the ANC has not met expectations; widespread anti-government protests — often led by ANC supporters - occur in response to the government's poor record of service delivery (Alexander, 2010). Opposition parties campaign using the ANC's institutional advantages against it.

The 2014 race provided voters choices representing different identities, interests, and policies. The ANC ran its controversial incumbent president Jacob Zuma. While few observers doubted the ANC's continued parliamentary majority, ${ }^{6}$ the ANC viewed any seat loss as a referendum on their performance. The death of Nelson Mandela a few months before the May 2014 election encouraged party leaders to formulate many of their appeals around "reminding" black South

\footnotetext{
${ }^{6}$ de Kadt (2017) shows that voting by black ANC supporters in 1994 increased their future likelihood of turnout.
} 
Africans of the ANC's role fighting apartheid. ANC stalwarts believed that stressing the party's legacy was important because they feared that "born free" voters - adults (18+) born after the end of apartheid - though eligible, would take the ANC for granted and not turn out in 2014 (Mattes, 2012).

The DA ran Helen Zille, the (white) former mayor of Cape Town; other (primarily black) parties included the the Economic Freedom Fighters (EFF), a new party formed by former ANC youth leader Julius Malema, and the Congress of the People (COPE), a party that first won seats in 2009 from ANC defections. The DA, EFF, and COPE leveraged the fact that many voters increasingly perceived Zuma as corrupt and expressed frustration at the ANC (Booysen, 2015); they put the government's performance at the front of their campaigns. A scandal relating to Zuma's usage of state funds to build an opulent rural home (Nkandla) dominated much of the presidential coverage. These parties also harnessed explicit economic messaging to compete for the ANC's base, running on substantive policy proposals regarding the economy, inequality, and unemployment. The 2014 unemployment rate (25\%) was the highest in a decade; over half of black youths were jobless; and a lack of services across sectors particularly affecting young, rural, black, female, and poor urban South Africans provided potential openings for opposition messaging (Southall, 2014b). The DA launched a ten-point platform, whose first two items focused on rooting out government corruption (read: ANC/Zuma) and promising six million new jobs. The EFF advanced a leftist agenda favoring expanded workers' rights and fighting inequality; Malema called for uncompensated expropriation of wealthy South Africans' land and nationalization of mines and banking (Mbete, 2015). Playing to moderate and middle class black voters, COPE advanced a market-oriented approach to improving growth and government efficiency.

The racial and institutional dynamics in South Africa therefore paint a mixed picture about how information-seeking voters might engage with news during campaigns. Apartheid's legacy and postapartheid ANC dominance suggest that beyond racial and party cues, voters exposed to additional information might ignore it. Yet ANC voter fatigue suggests that opposition parties could chip 
away at the ANC vote. The results from 2014 demonstrate this tension between ANC stability and opposition gains. The ANC ultimately won $62 \%$ of the vote (249 seats), losing 15 seats (4\% of voteshare) from 2009. The DA outperformed media expectations by gaining $22 \%$ (89 seats, a pick-up of 18), and the EFF achieved 6\% (25 seats) and COPE less than 1\% (losing 27 seats).

\section{$5 \quad$ Research Design}

We outline our data collection and research design (and direct readers to the Appendices for further details). Our empirical goal is to examine news reports to assess the CIE by first measuring the differences in the content of our categories of "narrow" and "broad" definitions of election and second the associations of different types of cues and whether they cluster with the main candidates and parties. Analyses of news coverage paint an important picture of the actual content of the campaign insofar as politicians want the press to cover their activities to publicize appeals to influence voters' CIE. Our goal is not to account for all factors that shape the entirety of a voter's CIE, an impossible task in any event. Instead, we leverage a novel corpus and machine learning to offer a window into understanding how variation in definitions of election-related content and coverage importantly shapes the CIE and generates fundamentally different perspectives of the information that voters are exposed to, when they are exposed, and how, during campaigns.

Admittedly, news reports provide only one avenue into the CIE and are necessarily incomplete in portraying the totality of voters' campaign exposure. Stories covered by the media will miss some political events. If certain events or types of events are not systematically reported on, but voters gain election-related information from learning about them, media reports may bias our understanding of the true underlying features of the campaign. For example, voters' direct contact with political actors may influence their CIE. However, we do not think that news reports present a biased representation of campaign exposure in South Africa. In Appendix A, analyses using Afrobarometer data show that respondents who report contact with politicians are only 
approximately five percentage points more likely to consume rates of regular news consumption compared to those who do not report contact. This suggests news is an important tool reflecting the actual content of the campaign and reinforces, rather an undercuts, incidents of direct contact. We address further potential sources of bias below. While imperfect, our approach provide an important first step in mapping tools to study the CIE and election-relatedness of the news to generate a more comprehensive and empirically-informed picture of heuristics available to voters analyzed on the most complete dataset available with the appropriate methodological tools.

\subsection{Data \& Methodology}

\section{Newspaper Corpus}

Our newspaper corpus consists of 97,428 articles from 167 South African newspapers for the period from 53 days before the 2014 election (March 15, 2014) to 23 days after the election (May 30, 2014). We constructed the corpus by scraping the websites of South African daily or weekly newspapers that publish their stories online. ${ }^{7}$ In total, we scraped 23 of the 37 print publications with the highest circulation in 2014. Appendix C describes our data collection process and lists publications. We curated and sampled publications in partnership with South African independent journalists, guidance from the South African Audience Research Foundation (SAARF), and the holdings of the major news conglomerates. Since these publications include South Africa's largest national newspapers in all three major print languages as well as with many smaller local publications, it forms a reasonable approximation of the voter's actual CIE and avoids bias in coverage of certain regions or segments of the country's population. We only included publications from which we could legally freely download articles and collected all available articles without regard to the article content.

\footnotetext{
${ }^{7}$ We scraped all available to us except for six that were behind paywalls and nine that had very restrictive usage agreements.
} 


\section{Topic Model}

A topic model produces a simplified representation of a collection of documents by representing each document as a distribution of topics and each topic as a distribution of words. We estimated a 32topic topic model to understand the content of our newspaper corpus ${ }^{8}$ using the parallel variational LDA algorithm (Hoffman et al., 2010) implemented in the Python package Gensim (Řehưřek and Sojka, 2010). The pre-processing pipeline of our corpus prior to estimating a topic model consisted of the following steps. With our corpus, we tokenized, part-of-speech (POS) tagged recognized namedentities (NER), and dependency parsed the corpus with SpaCy. ${ }^{9}$ We combined all recognized named entities into single tokens (e.g., "Jacob Zuma" treated as single token), and de-duplicated important South African individuals, organizations, and places using pattern matching and converted them to a canonical form (e.g. "ANC" replaced with "African National Congress"). ${ }^{10}$

\section{Election Related Articles}

To classify the election-relatedness of articles, we labelled a simple random subset of 1,000 articles (approximately 1\%) into three categories: "Narrowly" election-related (11\%), "Broadly" electionrelated $(14 \%)$, and not election-related (74\%). ${ }^{11}$ Political actors or institutions specifically related to or mentioning the election or election day were coded as narrow (e.g., mentions of president Jacob Zuma, the ANC and DA, voter registration, and ballot counting). Mention of any political actor or institution was coded as broad whether the story specifically related to the election or not; broad therefore picks up the same coverage as narrow as well as mentions of government agencies not directly related to the election race or the electoral process (e.g., health ministry, police,

\footnotetext{
${ }^{8}$ We choose 32 topics due to its better predictive performance in predicting election-relatedness categories in Section 6.1 over $16,64,75$, and 128 .

${ }^{9}$ We used SpaCy 1.9.0 and the en_core_web_md-1.2.1 model.

${ }^{10}$ In many applications of topic models in political science, scholars choose from a set of stemming and pattern-based tokenization options Denny and Spirling (2018). Our tokenization and lemmatization is based on a full language model and our choices of which tokens to keep and combining tokens for entities is determined by our analysis objectives. Appendix D provides additional information.

${ }^{11}$ Appendix A provides more information on coding.
} 
prosecutors). Coders continued using these two conceptions of election-relatedness, generating a three category classification system for all the sample: "narrowly election-related," "broadly election-related," and "non-election related" (for stories that did not mention any political actor or government agency). ${ }^{12}$ Appendix A provides a descriptive sense of the type of stories that are typical of both broad and narrow categories.

We use these labelled documents both to predict the election-relatedness of the remaining articles in the corpus (Section 6.1) and to understand the content of election-relatedness of articles (Section 6.2). ${ }^{13}$ In order to understand the content of the articles in each category, we estimated a topic model to generate topics for each article and then regressed these topics on these categories. Since we labelled only a subset of the articles, we predict the labels for the remaining unlabelled articles using a Lasso regression with a multinomial response trained on all the labelled articles. ${ }^{14}$ The features used in this model include topics from the topic model, days to the election, article language, publication, and publication owner. In subsequent analyses, we use the label if it was labelled and the predicted category otherwise as the election-related category of articles in the full corpus.

We consider three different measures of the relationship between topics and the election-relatedness categories, calculated from the point estimates of the document-specific topic-proportions and the labelled or predicted categories of the documents. The first is the probability that a topic is electionrelated given its topical content. This is the conditional probability that a piece of text is in category $c$ given it drawn from topic $k$,

$$
\hat{p}(\text { category }=c \mid \text { topic }=k)=\frac{\sum_{d \in D} \hat{p}(\text { category }=c \mid d) \hat{p}(\text { topic }=k \mid d)}{\sum_{d \in D} \hat{p}(\text { topic }=k)}
$$

\footnotetext{
${ }^{12}$ Using non-experts or distributed working platforms such as mTurk was not a viable option since the task required both knowledge of elections generally and South African politics specifically. While such a population may reside in South Africa, mTurk has limited workers to India and the United States since 2013. Testing the replicablity of expert coding using crowd-sourcing in Africa is an avenue for future potential research. Benoit et al. (2016), using Crowdflower and aggregating over 26 Crowdflower channels with 216,107 codings, obtained a total of 722 (.3\%) from eight South African workers.

${ }^{13}$ Subsequent analysis used $900(0.9 \%)$ labelled documents after cleaning and pre-processing of the corpus.

14 We used the Lasso implementation in the R package glmnet (Friedman et al., 2010) and rsample for crossvalidation (Kuhn and Wickham, 2017). Using a 10-fold cross-validation stratified by outcome category to approximate the out-of-sample error, this method had an accuracy of $85 \%$ and an expected log-loss of -0.21 .
} 
for $d \in 1: D$ documents.

The second measure asks what is the probability of a topic in a document from the broad, narrow, or non-election category. This is the conditional probability of topic $k$ given category $c$, estimated as

$$
\hat{p}(\text { topic }=k \mid \text { category }=c)=\frac{\sum_{d \in D} \hat{p}(\text { topic }=k \mid d) \hat{p}(\text { category }=c \mid d)}{\sum_{d \in D} \hat{p}(\text { category }=c)} .
$$

The third measure asks how much do learn about the election relatedness of a document from knowing that it is in a given topic. Unlike the first measure, this accounts for the baseline proportions of the categories and topics. We calculate this as,

$$
I G(\text { category }=c, \text { topic }=k)=\frac{p(\text { category }=c \mid \text { topic }=k) \log \left(\frac{p(\text { category }=c \mid \text { topic }=k)}{p(\text { category }=c)}\right)}{-\log p(\text { category }=c)} .
$$

This can be thought of as a "signed relative information gain" statistic, representing how much more likely (or unlikely) that document $d$ has category $c$ after observing that it has topic $k$ versus the prior probability that document $d$ had category $c$. The denominator is the maximum that observing the topic could increase the probability, i.e., when $p($ category $=c \mid$ topic $=k)=1$, which standardizes the statistic so that 0 means that observing a topic does not change the probability of a category and 1 means that observing a topic makes the presence of a category certain. This statistic is similar to lift (Taddy, 2012) and topic distinctiveness (Chuang et al., 2012). 


\section{Results}

\subsection{When is the Election?}

We first investigate whether time-period constitutes variation in "election" and whether coverage varies as the election approaches. While voting for the 2014 South African general election occurred on May 7, 2014, the term "2014 South African general election" could be interpreted as referring to a more extensive period of time encompassing a set of events occurring temporally close to the vote and its outcome.

We measure the extent of campaign coverage by period around election day, looking first at the prevalence of the mentions of the largest political parties and their leaders (Zuma/ANC, Zille/DA, Malema/EFF) in Appendix Figure F.4. Unsurprisingly, Zuma and the ANC receive the most coverage before, during, and after the election. Interestingly, Malema had a higher mean and peak coverage than Zille, despite the EFF receiving a lower vote share than the DA. Second, we examine the overall proportion of election related articles using the broad and narrow categories over time. On average, including both the broad and narrow categories accounted for 0.44 of total articles, with a range of between 0.31 to 0.67 and the maximum fraction occurring on election day. The bottom panel of Figure F.5 shows that this change in coverage is primarily due to the change in narrow coverage, not additional broad coverage. On average, including narrow categories accounted for 0.54 of all election-related articles, with a range of between 0.41 to 0.77 and the maximum "narrow" fraction occurring on election day. ${ }^{15}$

These results show that politically relevant coverage is approximately constant, but the content focused specifically on candidates and parties increased significantly approximately two weeks before the election. Highly engaged voters would therefore have received information in the months before

\footnotetext{
${ }^{15}$ We also examine this trend by language of article in Appendix Figures F.6 and F.7. Overall, there is higher average electoral coverage in English than in Afrikaans. The Afrikaans papers cover Zille and the DA, but give very little coverage to other parties or political figures. The only entirely isiZulu paper is heavily political.
} 
the election, but closer to election day, any potential voter consuming the news was reasonably exposed to coverage of the candidates and parties contesting office.

\subsection{What Election-Related Topics are Covered?}

We now turn to topic-content in detail to investigate variation in broad (Table 1) and narrow (Table 2) coverage. We first summarize preliminary findings regarding the consistency and information-gain in each category. Table 1 shows word associations in the broad classification are consistent with each other within the same topic $(p(C \mid T)$ values between 0.60 and 0.24$)$; the topic models unsurprisingly become more internally consistent for the narrow categories in Table $2(p(C \mid T)$ values between 0.86 and 0.25 ). Comparing the first column of Tables 1 and 2, topics are more exclusive in narrow compared to broad, as expected. The broad category includes many more topics than the narrow category, and the topics most associated with the broad category are less informative than those most associated with the narrow category. The third columns of Tables 1 and 2 show how much is learned about the category of a document given a topic (value of 1 meaning that we are certain about the category after observing a topic and 0 meaning that we have learned nothing about the category of the document). The most informative topics in the narrow category are more informative than those of the broad category. However we measure it, the narrow definition is related to a few topics

that primarily appear only in election-related articles, whereas the broad category encompasses a wider variety of topics that may or may not primarily appear in election-related articles, consistent with our theoretically-informed definitions of election coverage. 


\begin{tabular}{|c|c|c|c|c|}
\hline Topic & Topic label & $p(C \mid T)$ & $p(T \mid C)$ & $I G(T, C)$ \\
\hline \multirow[t]{2}{*}{7} & 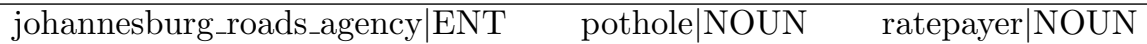 & 0.60 & 0.12 & 0.41 \\
\hline & $\begin{array}{l}\text { tenant|NOUN refuse|NOUN vagrant|NOUN bylaw|NOUN sinkhole|NOUN } \\
\text { mayoral_committee|ENT moqhaka|ENT }\end{array}$ & & & \\
\hline 13 & $\begin{array}{l}\text { eskom|ENT outage|NOUN cable|NOUN shedding|NOUN geyser|NOUN } \\
\text { heater|NOUN password|NOUN grid|NOUN solar|ADJ nersa|ENT }\end{array}$ & 0.46 & 0.04 & 0.24 \\
\hline 2 & $\begin{array}{l}\text { affidavit|NOUN sequestration|NOUN mona|ENT sassa|ENT asa|ENT } \\
\text { mdluli|ENT blower|NOUN summon|NOUN npa|ENT disciplinary|ADJ }\end{array}$ & 0.36 & 0.08 & 0.13 \\
\hline 15 & $\begin{array}{l}\text { agriculture|NOUN ndp|ENT abject|ADJ gordhan|ENT inequality|NOUN } \\
\text { wing|VERB nene|ENT } \quad \text { disadvantage|VERB } \\
\text { nhlanhla_nene|ENT }\end{array}$ & 0.33 & 0.03 & 0.10 \\
\hline \multirow[t]{2}{*}{21} & index|NOUN $\quad$ currency|NOUN & 0.31 & 0.05 & 0.08 \\
\hline & $\begin{array}{l}\text { lending|NOUN lender|NOUN economist|NOUN ounce|NOUN alibaba|ENT } \\
\text { inflation|NOUN }\end{array}$ & & & \\
\hline 31 & $\begin{array}{l}\text { virus|NOUN vaccine|NOUN flu|NOUN college_easter_rugby_festival|ENT } \\
\text { compost|NOUN cervical|ADJ owl|NOUN world_health_organisation|ENT } \\
\text { infection|NOUN obesity|NOUN }\end{array}$ & 0.29 & 0.02 & 0.07 \\
\hline 19 & $\begin{array}{l}\text { amcu|ENT lonmin|ENT vavi|ENT miner|NOUN } \\
\text { national_union_of_metalworkers_south_africa|ENT } \\
\text { palestinians } \mid \text { ENT anglo_american_platinum|ENT }\end{array}$ & 0.27 & 0.02 & 0.05 \\
\hline 10 & $\begin{array}{l}\text { astrazeneca|ENT broadband|NOUN telescope|NOUN locomotive|NOUN } \\
\text { transnet|ENT wi-fi|ENT cell_c|ENT nef|ENT prasa|ENT metrorail|ENT }\end{array}$ & 0.26 & 0.05 & 0.04 \\
\hline 9 & $\begin{array}{lrr}\text { news24|ADJ disclaimer|NOUN } & \text { mynews24|ENT } & \text { news24.com|ENT } \\
\text { psychopath|NOUN news24|ENT } & \text { racism|NOUN } & \text { reserve|VERB } \\
\text { capitalism|NOUN zak|ENT } & & \end{array}$ & 0.26 & 0.06 & 0.04 \\
\hline 26 & $\begin{array}{llrr}\text { pupil|NOUN } & \text { classroom|NOUN } & \text { bursary|NOUN } & \text { learner|NOUN } \\
\text { principal|NOUN mathematic|NOUN } & \text { scholarship|NOUN } & \text { epilepsy|NOUN } \\
\text { department_of_education|ENT teacher|NOUN } & & \end{array}$ & 0.24 & 0.06 & 0.03 \\
\hline
\end{tabular}

Table 1: Topics associated with the Broad categories. 


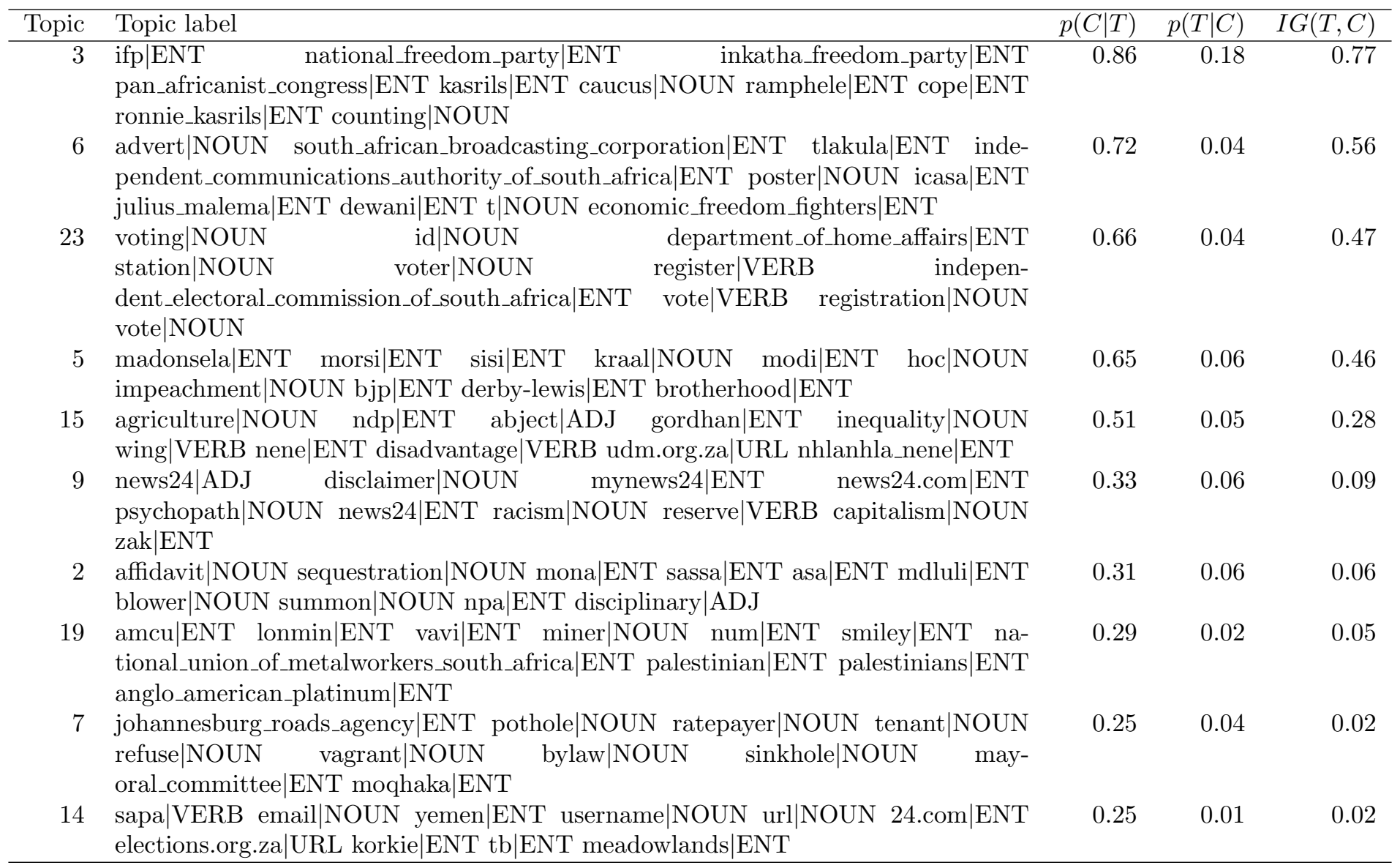

Table 2: Topics associated with the Narrow categories. 
Next, we discuss core results within the broad and narrow categories to demonstrate our coding schema qualitatively. Table 1 shows broad coverage. With an expansive definition, all ten topics are related to public services and government actors and policies across sectors, ${ }^{16}$ including content that is clearly political but not always obviously related to elections. Topic $7(p(C \mid T)=0.60)$ is associated with government service provision around roads and the roads agency ("pothole," "sinkhole,") and property ("ratepayer," "tenant," "vagrant"). Without necessarily specifying anything election-related, government actors are also listed in Topic 7 ("johannesburg_roads_agency," "mayoral_committee," and "moqhaka" [a municipality in Free State province]), including the bodies responsible for the service provision. Similarly, Topic $13(p(C \mid T)=0.46)$ relates to electricity and power provision ("outage," "cable," "shedding," "grid," "solar," "geyser") and agencies responsible for provision ("eskom,"17 "nersa"18).

Even the less predictive topics in Table 1 relate to politics and service provision by political agents. Topic 19 involves the mining sector and its managing institutions; Topic 9 covers news and telecommunications; and Topic 26 is about education, the department of education, teachers, and principals. Insofar as citizens attribute service provision to government actors and agencies, and use that in their electoral decisions, a broad classification provides information on the quality of services and many responsible agencies. The campaign gains salience as a person increasingly links these outcomes to the incumbent party or competing parties running on relevant valence issues.

Table 2 presents narrow coverage. Similar to broad, certain narrow topics enjoy a high likelihood of being associated with the narrow category (high $p(C \mid T)$ values). Moreover, the narrow category demonstrates our theoretical point qualitatively that election-coverage with a narrow definition includes content that is unambiguously related to the election and cues electoral competitors and institutions. Topic 3 includes words related to campaign coverage as well as names of parties and

\footnotetext{
${ }^{16} 7=$ roads, trash, property; $13=$ electricity/power; $2=$ justice, police, crime; $15=$ inequality/rural poverty; 21 $=$ exchange rates, currency; $31=$ public health; $19=$ mining; $10=$ communication and transport; $9=$ news; and 26 $=$ public education.

${ }^{17}$ South Africa's public utility provider.

${ }^{18}$ South Africa's energy regulatory body.
} 
individuals, like Ronnie Kasrils, a former Communist Party politician, who was not competing in the election but spearheaded a campaign urging voters to spoil their ballots. Topic 23 contains words on election administration and voting.

More clearly than broad, the associations within narrow topics show that parties and actors are associated with issues and items given their campaign messaging; however, only when they are able to generate their own topic of coverage. In Topic 6, ICASA is mentioned alongside the EFF, the party that proposed the ad about the mining sector that ICASA banned. For those voters consuming news, Topic 6 demonstrates how news coverage highlighted a link between EFF and the mining sector. ANC and DA, on the other hand, do not have topics that distinguish their narrow election-related coverage. This suggests that consumers of news stories sometimes got the substantive cue (e.g., job creation) independent of the actor most associated with it (e.g., DA), even if voters plausibly attributed past government action with the ANC.

Narrow coverage is qualitatively tighter than broad coverage in line with our expectations; Topic 15, containing words linking programmatic policies specifically to politicians' campaign appeals during the 2014 electoral cycle, is the only topic to appear in both categories. But results from the narrow category provide additional and consistent findings to those from broad by demonstrating that less engaged voters' CIE contained many clear election-related signals.

The topics paint an interesting picture of the CIE. From a broad perspective, information-seeking voters would have consumed a rich diet of election content that may have played a role in their electoral choices if engaged voters attribute service and policy outcomes to government action or parties contesting valence issues. However, the information contained in some broad topics is not always overtly political or related to electoral dynamics much beyond coverage of the government. The CIE for less engaged voters provides more content explicitly related to the election. Not all parties enjoyed the same ability to generate their own coverage. All told, both categories presented information-seeking voters with rich and extensive aspects of political actors and institutions in the CIE; while a narrow CIE does not always provide the most obvious heuristics related to fixed social 
and institutional dynamics, a broad CIE also does not necessarily create inconsistent or very noisy signals on substantive concerns that affect citizens' well-being.

\subsection{How are Parties and Politicians Covered?}

Next, we analyze how parties and politicians are covered in the campaign. First, we re-use the results of the topic model discussed above. Recall that in a topic model each document has a distribution of topics, and each topic has a distribution of words. This model implies that words can be associated with different topics, and the probability that a word comes from a given topic can vary depending on the document it is in due to the other words in that document. Due to our pre-processing steps, we are able to estimate the topics associated with parties and their leaders.

Figure 1 plots the probability that a usage of a political party or its leaders is associated with a topic. Most parties and party leaders only appeared in Topic 3, which we interpret as basic campaign coverage. Illustrative of only receiving basic coverage in Topic 3 is Zanele KamgwazaMsibi, a former Inkatha Freedom Party politician who founded a new party in 2014 (National Freedom Party). Kamgwaza-Msibi did not receive coverage outside of Topic 3; therefore, voters likely did not receive strong cues about her candidacy via the news. Conversely, individuals and parties that are relatively spread out among topics have a broader array of coverage across a range of topics. Depending on the meaning of topic, this coverage may help or hinder their campaign. For example, Malema appears in Topic 6, which includes words associated with his complaints to the Independent Communications Agency of South Africa (ICASA) about a banned advertisement featuring a woman whose husband was shot during mining protests. The coverage of the banned ad was likely important in drumming up support for Malema among workers in the mining sector. Consistent with our other findings, the news covered the DA and the ANC similarly, although the

DA received somewhat more coverage in Topic 6. Uniquely, Zuma had coverage in Topic 5, related to the Nkandla corruption scandal. Zille did not have coverage in an exclusive topic. 

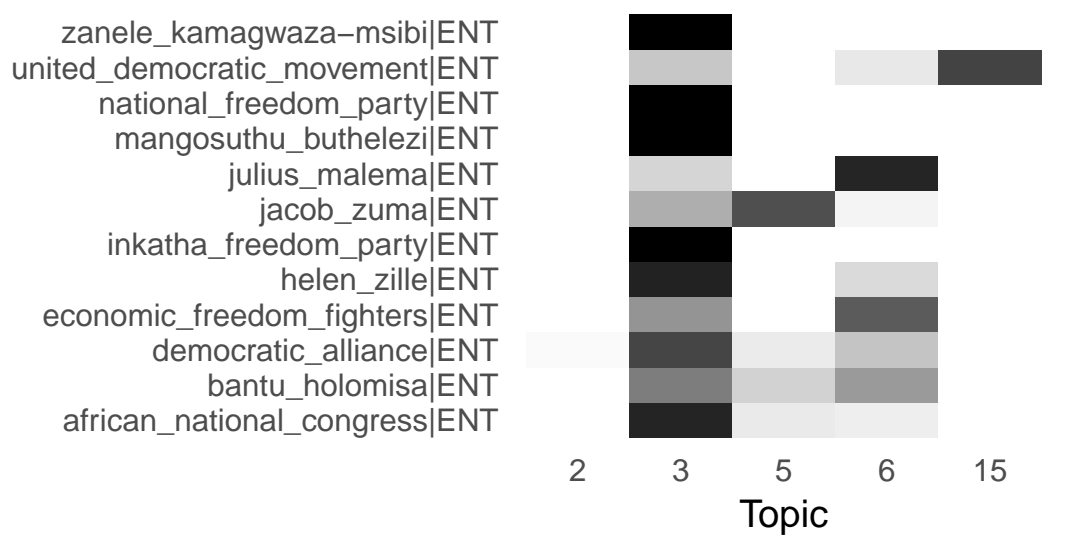

\section{P(topic | word)}

0.000 .250 .500 .751 .0

Figure 1: For the top parties and their leaders, the probability of a topic given the word.

Second, we use word vectors to examine the relationship between actors and tokens (e.g, "Zuma" with "corruption") and whether certain words cluster. Like topic models, word vectors are based on the assumption that words that co-occur more often with each other are more related. However, whereas topic models use co-occurrence in the entire document, words vectors use local cooccurrence (within a few words), which pick up different aspects of meaning. As explained in Appendix G, we run both time-varying and time-invariant word vector models and calculate the cosine similarity between all nouns and verbs and the three highest vote-getting parties. We highlight the these parties' relationship to tokens present in Topic 15 (the only topic that was highly related to both the broad and narrow election categorizations). 


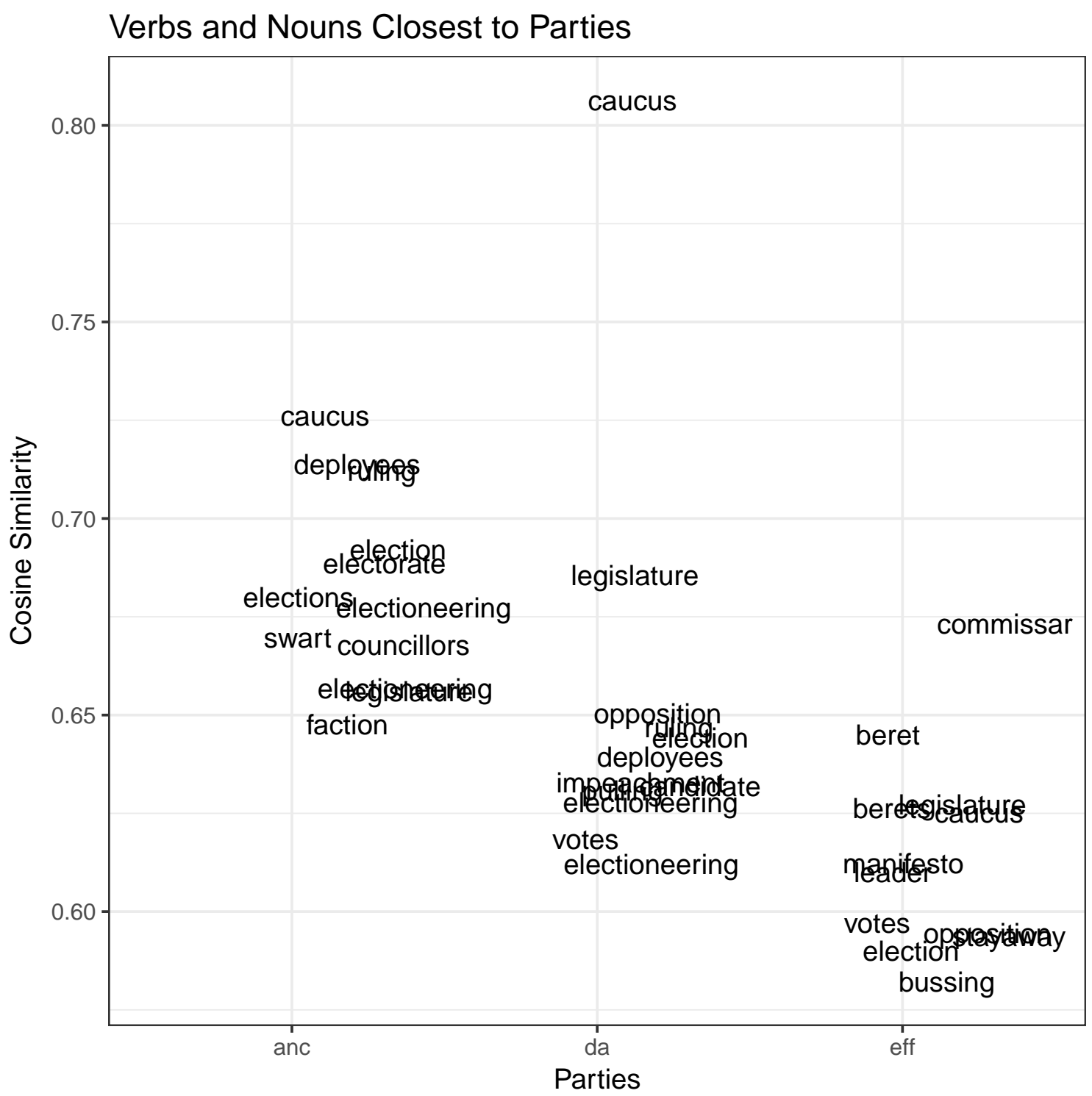

Figure 2: Time invariant word vectors, showing the nouns and verbs that are most similar to the three top vote-getting parties.

Figure 2 shows time-invariant relationships across all tokens for all nouns and verbs. The ANC and DA differ on words in their association with "ruling" and "opposition," reinforcing the idea that the DA is the most salient opposition party. "Faction" is associated with the ANC, potentially speaking to the internal strife within the ANC and threats of party defection. The DA and ANC are also associated with many of the same words, which we interpret as the two parties' general lack of ability to gain distinct coverage about themselves or signals about their positions. On the 
other hand, the EFF has different words associations focusing on their distinctive dress (beret) and organization (commissar) (Mbete, 2015), cuing their leftist orientation.

Figure 3 shows time-varying word vectors, displaying all of the nouns in the top 20 words of Topic 15 and their associations with the three main parties over time. Focusing on the relative association between campaign words and the parties, we note first that the parties shared coverage on some important issues and this maintains over time. With words like "poverty," "unemployment," and "inequality," the major parties enjoyed healthy amounts of coverage throughout the campaign. Because the parties aligned on promises to tackle certain valence issues, this finding is perhaps unsurprising; but our analysis shows that in so doing, no party gained a consistent upper-hand, broadly speaking. However, focusing on narrower points in time or other words, parties appear more dominant in coverage. Closer to election day, the ANC starts to increase its association with "inequality," "grazing," and "poverty;" signaling important themes for the ANC's base. ${ }^{19}$ Moreover, opposition parties are more associated with two words: "restitution" (DA, EFF) and "beneficiation" (DA). The DA opposed and the EFF championed restitution policies for black South Africans. Beneficiation refers to the policy of the mining industry improving the value of raw ore extraction through cutting and polishing; the DA consistently attacked the ANC's beneficiation policy.

Both topic models and word vectors provide evidence of content embedded within campaign stories and how specific cues are associated (or not) with relevant electoral actors. The two main parties, ANC and DA, distinguished themselves as a pair through information cues in the news, but overall, they were not differentiated from each other. This likely points to the DA as the main opposition party, which did not necessarily significantly distinguish itself from the ANC in terms of words associations beyond referencing government performance. Therefore, the DA's messaging likely reflected their condemnations of the ANC and Zuma more than anything specific to the DA, such as ideological orientation, other than its position as the leading opposition. In contrast, the

\footnotetext{
${ }^{19}$ Grazing is a concern for rural black constituents that lack access to land rights.
} 
EFF successfully signaled messaging that was consistently different than its two main competitors. Parties also demonstrate similar associations with some valence issues like unemployment and inequality — words that all parties ran on; but not others, like policies where the parties disagreed on solutions to issues.

A textured picture of South African voters' CIE emerges from these results. In some ways, election choices are clearly and consistently associated with the actors most likely to win on those issues, providing evidence that heuristics do not just exist in a vacuum. Yet in other ways, the CIE does not always reflect what many politicians most likely hope: that they are associated only with words that reinforce their messaging and distinguish their issues and policies from others. Voters are exposed to rich information alongside of obvious candidates and party cues; however, this information is often more complex and less statics than many politicians, scholars, and other observers may realize. 


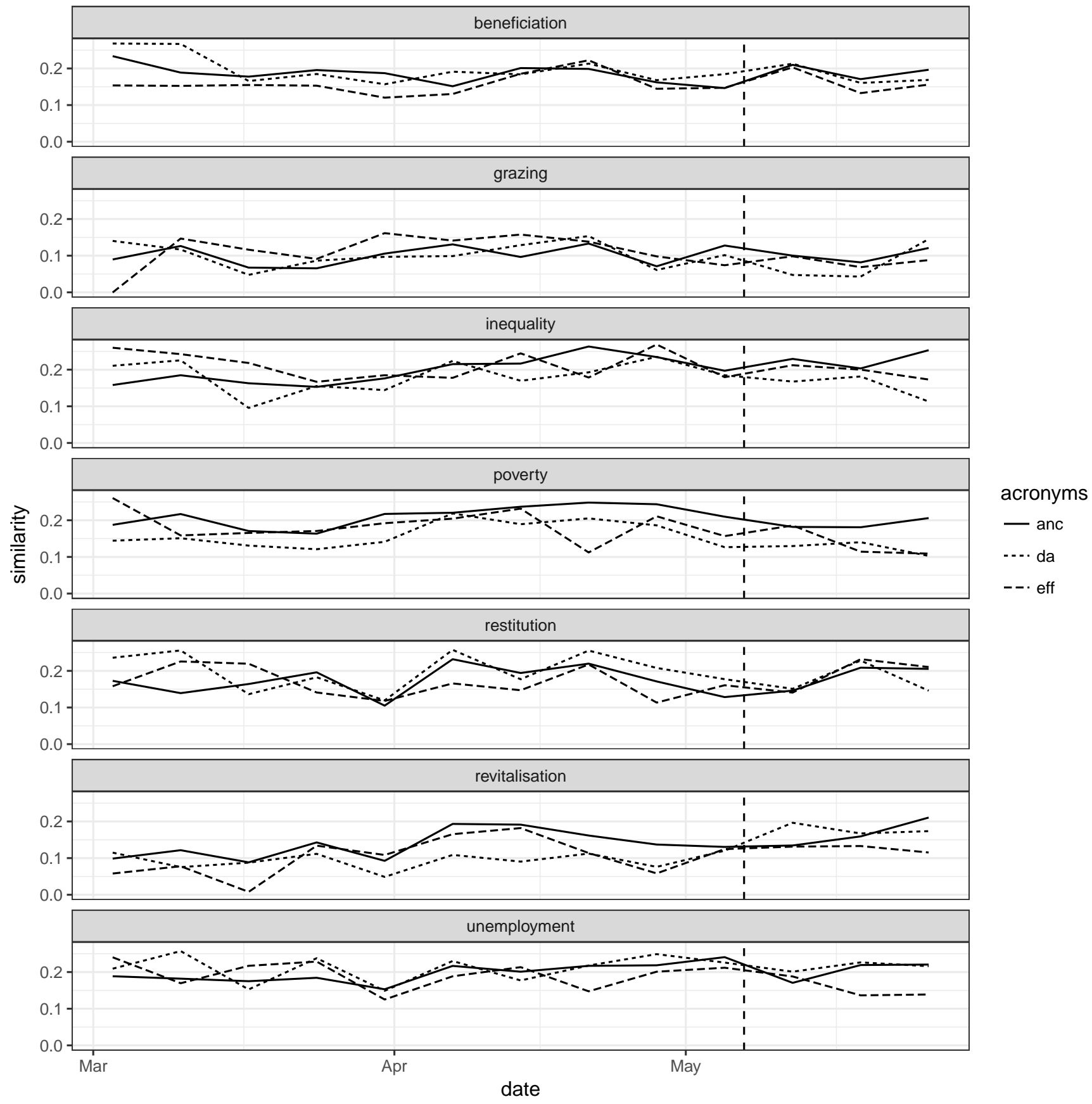

Figure 3: Time-varying word vectors for all of the nouns in the top 20 words associated with Topic 15. The dashed line shows election day. 


\section{Conclusion}

In this paper, we investigate campaign media coverage in an emerging democracy's election. Using machine learning on an extensive corpus of news stories, our results indicate that how one conceives of an election at the outset plays a critical role in measuring election coverage and the type of results that emerge from analysis. Even a narrow conception of election coverage provides rich details about the information environment beyond the racial and institutional cues generated from politicians' appeals, including coverage of the incumbent government's performance. A broad definition further provides news consumers with information about public policies and service provision outcomes. Word associations of campaign issues and policy stances cluster by political actors in ways that suggest that the CIE provides clear signals, not just noise, during the campaign.

Results from South Africa provide insights for understanding campaigns and elections in other emerging democracies. Voters have the potential to be exposed to new information that could influence their opinions by causing them to update their prior beliefs in the CIE. Even in South Africa where one party dominates and race correlates strongly with vote choice, the CIE may play an important role in influencing politics. Although Zuma won re-election in 2014, political competition among South African politicians should not be taken for granted. The ANC replaced Zuma as party leader and forced his resignation in 2018 ahead of the 2019 elections because of increasing corruption allegations against him, reported on extensively in the news. It is beyond the scope of our paper to say whether the CIE suggests greater democratic consolidation if the campaign is becoming more "substantive," or whether debates over policies and valence issues will play a role in future elections. But our results indicate that the CIE in emerging democracies demonstrates that in addition to the fundamentals, information-seeking voters engaged with the campaign consume rich and textured news about political actors and institutions before casting ballots. 


\section{References}

Adida, Claire L. (2015). Do African Voters Favor Coethnics? Evidence from a Survey Experiment in Benin. Journal of Experimental Political Science 2(1), 1-11.

Alexander, Peter (2010). Rebellion of the poor: South africa's service delivery protests - a preliminary analysis. Review of African Political Economy 37(123), 25-40.

Alvarez, R. Michael (Ed.) (2015). Computational Social Science: Discovery and Prediction. New York: Cambridge University Press.

Bagozzi, Benjamin E. and Philip A. Schrodt (2012). The Dimensionality of Political News Reports. http://www. benjaminbagozzi.com/uploads/1/2/5/7/12579534/bagozzi.schrodt. epsa12.pdf.

Banducci, Susan A. and Jeffrey A. Karp (2003). How Elections Change the Way Citizens View the Political System: Campaigns, Media Effects and Electoral Outcomes in Comparative Perspective. British Journal of Political Science 33(3), 443-467.

Barkan, Joel D. (1976). An African Dilemma: University students, development, and politics in Ghana, Tanzania, and Uganda. New York: Oxford University Press.

Beieler, John (2016, October). The Generation and Use of Political Event Data. Ph. D. thesis, Pennsylvania State University.

Benoit, Kenneth , Drew Conway, Benjamin E. Lauderdale, Michael Laver, and Slava Mikhaylov (2016). Crowd-sourced Text Analysis: Reproducible and Agile Production of Political Data. American Political Science Review 110(2), 278-295.

Besley, Timothy (2005, August). Political Selection. Journal of Economic Perspectives 19(3), $43-60$. 
Bischof, Jonathan M. and Edoardo M. Airoldi (2012). Summarizing topical content with word frequency and exclusivity. In Proceedings of the 29th International Coference on International Conference on Machine Learning, ICML'12, USA, pp. 9-16. Omnipress.

Blaydes, Lisa (2011). Elections and Distributive Politics in Mubarak's Egypt. Cambridge: Cambridge University Press.

Bleck, Jaimie and Nicolas van de Walle (2013). Valence Issues in African Elections: Navigating Uncertainty and the Weight of the Past. Comparative Political Studies 46(11), 1394-1421.

Booysen, Susan (2015). Election 2014 and the Anc's Duet of Dominance and Decline. Journal of African Elections 14(1), 7-34.

Bratton, Michael and Mwangi S. Kimenyi (2008). Voting in Kenya: Putting Ethnicity in Perspective. Journal of Eastern African Studies 2, 272-289.

Bratton, Michael, Robert Mattes, and Emmanuel Gyimah-Boadi (2005). Public opinion, democracy, and market reform in Africa. Cambridge University Press.

Carlson, Elizabeth (2015). Ethnic Voting and Accountability in Africa: A Choice Experiment in Uganda. World Politics 67(2), 353-385.

Chandra, Kanchan (2004). Why ethnic parties succeed. New York: Cambridge University Press.

Chuang, Jason , Christopher D. Manning, and Jeffrey Heer (2012). Termite: Visualization techniques for assessing textual topic models. In Advanced Visual Interfaces.

Conroy-Krutz, Jeffrey and Devra C. Moehler (2016). Eyes on the ballot: Priming effects and ethnic voting in the developing world. Electoral Studies 42, 99-113.

Coppedge, Michael, John Gerring, David Altman, Michael Bernhard, Steven Fish, Allen Hicken, Matthew Kroenig, Staffan I. Lindberg, Kelly McMann, Pamela Paxton, Holli A. Semetko, SvendErik Skaaning, Jeffrey Staton, and Jan Teorell (2011). Conceptualizing and Measuring Democracy: A New Approach. Perspectives on Politics 9(2), 247-267. 
de Kadt, Daniel (2017). Voting Then, Voting Now: The Long-Term Consequences of Participation in South Africas First Democratic Election. The Journal of Politics 79, 670-687.

Denny, Matthew J. and Arthur Spirling (2018). Text Preprocessing For Unsupervised Learning: Why It Matters, When It Misleads, And What To Do About It. Political Analysis 26(2), 168-189.

Dickson, Eric S. and Kenneth Scheve (2006). Social Identity, Political Speech, and Electoral Competition. Journal of Theoretical Politics 18(1), 5-39.

Downs, A. (1957). An Economic Theory of Democracy. New York: Harper \& Row.

Ferree, Karen (2011). Framing the race in South Africa: the political origins of racial census elections. Cambridge University Press.

Ferree, Karen and James D. Long (2016). Gifts, Threats, and the Secret Ballot in Africa. African Affairs 115, 621-645.

Friedman, Jerome , Trevor Hastie, and Robert Tibshirani (2010). Regularization paths for generalized linear models via coordinate descent. Journal of Statistical Software 33(1), 1-22.

Gibson, Clark C. , Karen E. Ferree, and James D. Long (2014). Voting behavior and electoral irregularities in kenya's 2013 election. Journal of Eastern African Studies 8(1), 153-172.

Habib, Adam and Naidu Sanusha (2006). Race, class and voting patterns in south africa's electoral system: Ten years of democracy. Africa Development 31(3), 81-92.

Hoffman, Matthew D. , David M. Blei, and Francis Bach (2010). Online learning for latent dirichlet allocation. In Advances in Neural Information Processing Systems.

Horowitz, Donald (1985). Ethnic groups in conflict. Berkeley: University of California Press.

Horowitz, Jeremy and James Long (2016). Strategic voting, information, and ethnicity in emerging democracies: Evidence from kenya. Electoral Studies 44, 351-361. 
Kelley, Judith G. (2012). Monitoring Democracy: When International Election Observation Works, and Why It Often Fails. Princeton University Press.

Kuhn, Max and Hadley Wickham (2017). rsample: General Resampling Infrastructure. CRAN. R package version 0.0.2.

Levitsky, Steven and Lucan A. Way (2010). Competitive Authoritarianism: Hybrid Regimes after the Cold War. Cambridge: Cambridge University Press.

Lindberg, Staffan and Minion K.C. Morrison (2008). Are african voters really ethnic or clientelistic? survey evidence from ghana. Political Science Quarterly 123(1), 95-122.

Lodge, Tom (2004). The african national congress and its allies. In A. Reynolds (Ed.), Election '94 South Africa: The Campaigns, Results and Future Prospects. New York: St. Martin's Press.

Lupia, Arthur and Matthew D. McCubbins (1998). The Democratic Dilemma: Can citizens learn what they need to know? Cambridge: Cambridge University Press.

Magaloni, Beatriz (2006). Voting for Autocracy: Hegemonic Party Survival and its Demise in Mexico. Cambridge: Cambridge University Press.

Mattes, Robert (2012). The 'born frees': The prospects for generational change in post apartheid south africa. Australian Journal of Political Science 47(1), 133-153.

Mattes, Robert and Jessica Piombo (2001). Opposition parties and the voters in south africa's general election of 1999. Democratization 8(3), 101-128.

Mattes, Robert and Roger Southall (2004). Popular attitudes toward the south african electoral system. Democratization 11(1), 51-76.

Mbete, Sithembile (2015). The Economic Freedom Fighters South Africa's Turn Towards Populism? Journal of African Elections 14(1), 35-59. 
Mebane, Walter R., Jr., Alejandro Pineda, Logan Woods, Joseph Klaver, Patrick Wu, and Blake Miller (2017, April 6-9.). Using twitter to observe election incidents in the united states. Prepared for presentation at the 2017 Annual meeting of the Midwest Political Science Association.

Munck, Gerardo L. and Jay Verkuilen (2002, February). Conceptualizing and Measuring Democracy Evaluating Alternative Indices. Comparative Political Studies 35(1), 5-34.

Nickerson, David W. and Todd Rogers (2014). Political Campaigns and Big Data. Journal of Economic Perspectives 28(2), 51-74.

Norris, Pippa (2014). Why electoral integrity matters. Cambridge University Press.

Popkin, S. (1994). The reasoning voter. Chicago: Chicago University Press.

Posner, D. (2005). Institutions and ethnic politics in Africa. Cambridge: Cambridge University Press.

Proksch, Sven-Oliver and Jonathan B. Slapin (2010). Position Taking in European Parliament Speeches. British Journal of Political Science 40(03), 587-611.

Řehưřek, Radim and Petr Sojka (2010, May). Software framework for topic modelling with large corpora. In Proceedings of the LREC 2010 Workshop on New Challenges for NLP Frameworks, Valletta, Malta, pp. 45-50. ELRA. http://is.muni.cz/publication/884893/en.

Reynolds, Andrew (1999). Electoral Systems and Democratization in Southern Africa. London and New York: Oxford University Press.

Reynolds, Andrew and Ben Reilly (1997). The International IDEA Handbook of Electoral System Design. Sweden: International Institute for Democracy and Electoral Assistance.

Ruths, Derek and Jürgen Pfeffer (2014). Social Media for Large Studies of Behavior. Science $346(6213), 1063-1064$. 
Salawu, Abiodun (2013). Stunted growth: An exploration into the failures of African-language newspapers, Imvo Zabantsundu in focus. Ecquid Novi: African Journalism Studies 34(2), 73-92.

Schrodt, Philip A. (2012). Precedents, Progress, and Prospects in Political Event Data. International Interactions 38(4), 546-569.

Southall, Roger (2014a). The south african election of 2014: Retrospect and prospect. Strategic Review for Southern Africa 36(2), 80-95.

Southall, Roger (2014b). Zuma: party leadership as electoral liability. Review of African Political Economy 41(140), 323-331.

Spirling, A (2015). Democratization and linguistic complexity: The effect of franchise extension on parliamentary discourse, 1832-1915. Journal of Politics 78(1), 120-136.

Stokes, Susan C. (2005). Perverse Accountability: A Formal Model of Machine Politics with Evidence from Argentina. The American Political Science Review 99(3), 315-325.

Stokes, Susan C, Thad Dunning, Marcelo Nazareno, and Valeria Brusco (2013). Brokers, voters, and clientelism: The puzzle of distributive politics. Cambridge University Press.

Taddy, Matthew A. (2012). On estimation and selection for topic models. In Proceedings of the 15th International Conferenceon Artificial Intelligence and Statistics (AISTATS).

Tomaselli, Keyan (1997). Ownership and control in the South African print media: black empowerment after apartheid, 1990-1997. Ecquid Novi 18(1), 67-68.

Wilkerson, John, David Smith, and Nicholas Stramp (2015). Tracing the flow of policy ideas in legislatures: A text reuse approach. American Journal of Political Science 59(4), 943-956. 


\section{Appendices}

\section{A South African News Consumption}

\begin{tabular}{|c|c|c|c|c|c|c|c|}
\hline & $\mathrm{n}$ & $(\%)$ & Never & i $1 \mathrm{x}$ month & Few $\mathrm{x}$ month & Few x week & Daily \\
\hline Total Newspaper Consumption & 2388 & & 22.8 & 9.5 & 15.9 & 24.4 & 27.3 \\
\hline \multicolumn{8}{|l|}{ Sex } \\
\hline Female & 1206 & 50.5 & 26.9 & 11 & 18.5 & 20.6 & 22.9 \\
\hline Male & 1184 & 49.5 & 19.5 & 8.3 & 14.4 & 26.1 & 31.6 \\
\hline \multicolumn{8}{|l|}{ Race } \\
\hline Black/African & 1665 & 69.7 & 26.8 & 10.2 & 17.5 & 22.6 & 22.9 \\
\hline White/European & 251 & 10.5 & 6.2 & 6.6 & 9.3 & 22.1 & 55.8 \\
\hline Colored/mixed & 327 & 13.7 & 19.7 & 11.1 & 17.7 & 24.8 & 26.3 \\
\hline South Asian & 142 & 5.9 & 1.1 & 0.8 & 9.6 & 37.9 & 50.6 \\
\hline Other & 5 & 0.2 & 100 & 0 & 0 & 0 & 0 \\
\hline \multicolumn{8}{|l|}{ Age } \\
\hline$[18,32.4]$ & 978 & 40.9 & 19.7 & 11.3 & 21.5 & 24.1 & 23.5 \\
\hline$(32.4,46.9]$ & 749 & 31.3 & 21.8 & 7 & 14.2 & 27 & 29.6 \\
\hline$(46.9,61.3]$ & 456 & 19.1 & 24 & 10.5 & 12.7 & 19 & 33.8 \\
\hline$(61.3,75.7]$ & 169 & 7.1 & 42.3 & 9.3 & 9.7 & 16.9 & 21.8 \\
\hline$(75.7,90.2]$ & 28 & 1.2 & 62.8 & 12.5 & 9.6 & 11.6 & 3.5 \\
\hline$(90.2,105]$ & 2 & 0.1 & 100 & 0 & 0 & 0 & 0 \\
\hline \multicolumn{8}{|l|}{ Education } \\
\hline No formal schooling & 69 & 2.9 & 78.2 & 7.1 & 6.8 & 2.5 & 5.4 \\
\hline Some primary / primary completed & 289 & 12.1 & 42.1 & 15 & 15.1 & 14.8 & 12.6 \\
\hline Some secondary / secondary completed & 1399 & 58.5 & 22.1 & 10.1 & 19.3 & 25.2 & 23.2 \\
\hline Post-secondary training (not uni.) & 351 & 14.7 & 13.6 & 7.1 & 10.5 & 30.4 & 38.4 \\
\hline Some university / university completed & 281 & 11.8 & 3.9 & 4.3 & 13.4 & 19.9 & 58.7 \\
\hline \multicolumn{8}{|l|}{ Water source } \\
\hline Inside home / compound & 1897 & 79.4 & 19.4 & 8.9 & 16.1 & 24.7 & 30.9 \\
\hline Outside compound & 478 & 20 & 35.1 & 12.8 & 18.4 & 18.6 & 14.9 \\
\hline \multicolumn{8}{|l|}{ Party affiliation } \\
\hline $\mathrm{ANC}$ & 965 & 40.4 & 28.6 & 11.2 & 16.8 & 22.4 & 20.7 \\
\hline COPE & 21 & 0.9 & 15.4 & 0 & 28.6 & 18.3 & 37.8 \\
\hline DA & 344 & 14.4 & 15.6 & 7.2 & 13.7 & 23.7 & 39.7 \\
\hline $\mathrm{EFF}$ & 148 & 6.2 & 20 & 11.1 & 12.9 & 26.5 & 29.5 \\
\hline No party & 746 & 31.2 & 20.4 & 8.3 & 16.1 & 25 & 30.1 \\
\hline Other & 87 & 3.6 & 19.8 & 8.8 & 19.5 & 22.7 & 29.1 \\
\hline
\end{tabular}

Newspaper consumpion by demographic group.

All data are taken from R6 of the Afrobarometer, and is weighted 


\begin{tabular}{lrrr}
\hline \multirow{2}{*}{ Political Contact? } & \multicolumn{3}{c}{ Frequency of Consumption } \\
\cline { 2 - 5 } Any News & Never & Less than 1x per month At least 1x per month \\
\hline $1 \quad$ No & 21.5 & 6.0 & 72.2 \\
$2 \quad$ Yes & 14.9 & 8.1 & 76.4 \\
\hline Newspaper & & & 65.3 \\
\hline $3 \quad$ No & 25.9 & 8.8 & 70.9 \\
\hline$\quad$ Yes & 17.4 & 11.5 & 44.0 \\
\hline Internet & & & 45.4 \\
\hline $5 \quad$ No & 51.6 & 4.2 & \\
$6 \quad$ Yes & 49.7 & 4.3 & \\
\hline
\end{tabular}

Political Contact during Past Year as Percentage of News Consumption.

Afrobaromter R6. Data are weighted.

\section{B Story Coding}

Two coders labelled the random subset. First, each coder was shown the full title and full text for an article and asked to select one of three possible labels: "Election-related," "Not election-related," and "Indeterminate." Before manually labelling the stories, two of the co-authors first coded a sample of 100 of the 1,000 stories and met to discuss inter-coder differences. After closely examining the differences in the understanding of "election-related," three of the authors reached the agreement that the difference between two of the authors was a difference between a narrow conception of electoral coverage and a broad conception of electoral coverage. Then another independent sample of 1000 stories were drawn, which two authors hand-coded. From these labels, we classified each document into one of the three categories.

\section{A Example Coded Stories}

In the narrow category, we display a story that reports on potential misconduct of the election commission (IEC) chairwoman Pansy Tlakula. Other typical "narrow" stories, as shown, cover police being deployed for election related-security and profile a march the DA organized for the 
elections to highlight ANC shortcomings. All these stories explicitly discuss election related matters.

A story reporting about a court case involving mineworkers is coded as "broad." Stories related to a mineworkers' strike that had been ongoing since 2013 and was about their wages was included but did not reference anything particular about the election and just happened to occur during the election cycle is coded broadly. Another example in the broad category involves stories about trucks damaging roads, specifically highlighting a public policy problem that could theoretically become an electoral issue. Again, the story does not tie the issue directly to the election campaign. A last example documents issues with Eskom, South African electric public utility. We also display "Non-election" related stories including such topics as music, space exploration, and sports.

\begin{tabular}{ll}
\hline category & text \\
\hline Non-election & Tokyo Canadian pop singer Justin Bieber, \\
& whose tumultuous life has landed him in \\
& trouble more than once, has apologised for \\
& a visit to ...- "Justin Bieber apologises af- \\
& ter Japan shrine visit sparks anger".City \\
& Press, April 23, 2014 \\
& Moscow - A Russian and an American re- \\
& turned to Earth on Wednesday with their \\
& Japanese commander aboard a Soyuz cap- \\
& sule in the first such ...- "Russia may stop \\
& US rides to ISS".News24, May 14, 2014 \\
& Madrid - Barcelona are focusing on a \\
& sweeping rebuilding effort after the Cata- \\
& lan giants ended the season without ma- \\
& jor silverware for th...- "Barca set for pro- \\
& found changes".Pretoria News, May 18, \\
& 2014
\end{tabular}


Narrow Opposition political parties say if their court application to force President Jacob Zuma to axe elections boss Pansy Tlakula fails, they...- "Opposition will march if Pansy Tlakula is not fired".City Press, April 20, 2014

Thousands of DA supporters are expected to take to the streets of Joburg to march against corruption and unemployment. "We will march for...- ".". Sandton Chronicle, April 23, 2014

Durban - KwaZulu-Natal will see 17000

police officers deployed across the province during the 7 May elections to ensure they take place ...- "17 000 police in KZN for elections".News24, April 29, 2014

Broad Johannesburg - South Africa wouldn't take sides in a wage strike that halted output at the largest platinum mines for more than six weeks...- "SA takes no sides in platinum strike, says president". The Mercury, March 9, 2014

SWARTKOPS residents say they have had enough of the influx of trucks which are causing damage to their roads infrastructure and endangeri...- "Swartkops residents fed up with trucks".Port Elizabeth Express, February 26, 2014

Cape Town - Eskom spent a whopping R10 billion on diesel last year to help keep the lights on. This was R8bn more than it had budgeted fo...- "Who will pay Eskoms R10bn diesel bill?". Independent Online, April 14, 2014

Table B.3: For each election relatedness category, three example articles.

\section{Newspaper Corpus Information}

The scraper software was developed in collaboration with Code for South Africa (Code4SA), a South African non-profit civic technology lab. The source code is available at https://github.com/ 
Code4SA/various-scrapers. This collection method restricted our sample of publications to those with a free website and excluded publications that had a paywall (Beeld, Volksblad), restrictive terms and conditions prohibiting scraping (The Sowetan and several Times Media Group publications), or only distribute a PDF version of their print copy (The Diamond Fields Advertiser). Our corpus also includes some online-only newspapers, most notably, News24.

Following Davenport and Moore (2015), our goal is to capture as many election-related stories as possible, but we could not obtain all election-related stories for two reasons. First, to receive news coverage at all, a story would need to be "newsworthy" insofar as it received any reporting and publication across our sample. Given the number of national and local news sources in our corpus, we believe that any story missing from coverage completely likely did not generate unique appeals or affect the information environment to such a large degree as to suggest bias in the nature of appeals we do pick up from reported events. Second, as noted, our corpus only includes all news stories available to us, a sample neither completely universal nor random. Our sample is therefore designed to obtain as complete as possible coverage of election-related reporting in the South African print media, but may miss some coverage only reported in papers not in our sample. Nevertheless, we believe our sample goes far beyond other efforts and attenuates source bias that may exist by only employing only a small number of well known media outlets (Reeves et al., 2006).

Our sample includes newspapers published in English, Afrikaans, and Zulu (isiZulu). Some smaller publications employ a combination of the three languages. English language dominance and the secondary market for Afrikaans language news reflect white dominance under British colonial rule and the subsequent apartheid era development of media in South Africa (Tomaselli, 1997). Table C.4 shows the top publications by number of articles in our data. The majority of all titles in the South African market publish in English. While English is the first language of less than 10 percent of the population, it is spoken widely as a second or third language.

We explicitly sought diverse language coverage because, as Holmes (2015, 278) notes, the majority of South African media analysis and research ignores the non-English press. Therefore, Table C.4 
shows a large Afrikaans market, which is the first language of approximately $14 \%$ of the population. IsiZulu is the African language which has witnessed the largest media growth, as a result of the relatively large population of speakers and Zulu's relatively high economic standing among black African groups (Ndlovu, 2011). Importantly, our data contains Isolezwe, the largest isiZulu publication in circulation. We note that no newspaper publications exist in the majority of South Africa's eleven recognized African languages (Salawu, 2013). In the corpus, 80,240 (82\%) articles were in English, 16,587 (17\%) articles were in Afrikaans, and 532 (1\%) articles were in isiZulu.

In addition to language diversity, our sample also includes titles from all of the main South African media conglomerates. Media ownership in South Africa in recent years has integrated into a few large conglomerates and globalized, with increasing foreign ownership. At the time of this study (2014), print media ownership in South Africa was highly concentrated in four firms (Angelopulo and Potgieter, 2016):

1. Caxton: Caxton publishers are known for their small free and community newspapers. Our samples included both their largest newspapers, as well as many smaller local newspapers.

2. Independent News and Media South Africa (INMSA)

3. Naspers/Media24

4. and the Times Media Group (TMG) (Formerly Avusa).

All conglomerates have English titles, however there is some differentiation in whether they own Afrikaans or isiZulu publications. Naspers/Media24 owned the major Afrikaans newspapers. INMSA had the only isiZulu publication in our sample, Isolezwe. 


\begin{tabular}{lrlr}
\hline Publication Name & No. of Articles & Language & Days in Corpus \\
\hline News24 & 13083 & English & 87 \\
Independent Online & 5974 & English & 109 \\
The Citizen & 4406 & English & 73 \\
Tame Times & 3961 & English & 101 \\
City Press & 2992 & English & 86 \\
Business Report & 2550 & English & 73 \\
Pretoria News & 2346 & English & 84 \\
VaalWeekblad & 1651 & Afrikaans & 95 \\
Worcester Standard & 1536 & Afrikaans & 56 \\
Daily News & 1462 & English & 45 \\
Mail \& Guardian & 1399 & English & 89 \\
Eikestad Nuus & 1314 & Afrikaans & 84 \\
The Witness & 1136 & English & 49 \\
Weslander & 1121 & Afrikaans & 194 \\
Kalahari Bulletin & 1092 & Afrikaans & 92 \\
Boland Gazette & 1047 & Afrikaans & 111 \\
Daily Sun & 1008 & English & 80 \\
Potchefstroom Herald & 983 & Afrikaans & 78 \\
Tygerburger & 959 & English & 105 \\
Paarl Post & 917 & Afrikaans & 53 \\
\hline
\end{tabular}

Table C.4: Top 20 publications in the corpus, by number of articles. There are 97,428 articles total in the corpus.

\section{A Top Publications}

\section{B All Publications in Corpus}

African Reporter, Alberton Record, Alex News, Ballito Fever, Ballito News, Bedfordview and Edenvale News, Benoni City Times, Berea Mail, Bloem Nuus, Boksburg Advertiser, Boland Gazette, Brakpan Herald, Britspos, Business Report, Camaro Chronicle, Cape Argus, Cape Business News, Cape Times, Capricorn Review, Carltonville Herald, Centurion Rekord, Chiawelo Urban News, City Buzz, City Press, City Vision, Coastal Weekly, Corridor Gazette, Daily Dispatch, Daily News, Daily Sun, Die Son, Diepkloof Urban News, DistriksPos, Dobsonville Urban News, Durban North Fever, East Griqualand Fever, East London Express, Eden Express, Edendale Echo, Eikestad Nuus, Eldorado Urban News, Estcourt and Midlands News, Express Paper, Eyethu News KZN, Financial Mail, Fourways Review, Franco - SA, Gemsbok, Germiston City News, Greytown Gazette, Hammanskraal News, Hazyview Herald, Herald's Bonus, Hermanus Times, Highvelder, Highway Mail, Hillcrest Fever, Independent Online, IQ4 News, Isolezwe, Isolomzi Express, Jabavu Urban News, JBay News, Joburg East Express, Kalahari Bulletin, Kempton Express, Kerksdorp Record, Klerksdorp Record, Kouga Express, Kroonnuus, Krugersdorp News, Ladysmith Gazette, Leseding News, Lowvelder, 
Mafikeng Mail, Mail \& Guardian, Makhado Review, Maluti, Maritzburg Echo, Maritzburg Fever, Maritzburg Sun, Matimu News, Meadowlands Urban News, Midrand Reporter, Mpulanga News, Mpumalanga News, Mthatha Express, Nelspruit Post, Newcastle Advertiser, News24, Noordkaap, Noordwester, North Coast Courier, North Glen News, Northcliffe Melville Times, Northeastern Tribune, Ons Stad, Orlando Urban News, Paarl Post, Parys Gazette, People's Post, Pimville Urban News, Polokwane Express, Polokwane Observer, Port Elizabeth Express, Potchefstroom Herald, Pretoria East Rekord, Pretoria Moot Record, Pretoria News, Pretoria North Rekord, Protea Urban News, Public Eye Maritzburg, Public Eye News, Randburg Sun, Randfontein Herald, Rapport, Review Bosveld, Review Online, Ridge Times, Rise 'n Shine, Roodepoort Northsider, Roodepoort Record, Roodeport Northsider, Rosebank Killarney Gazette, Rustenburg Herald, Sandton Chronicle, Sedibengster, SME South Africa, South Coast Fever, South Coast Herald, South Coast Sun, Southern Courier, Southlands Sun, Springs Advertiser, Standardton Advertiser, Standerton Advertiser, Steelburger Nuus, Stellalander, Stranger Weekly, Sunday Tribune, Sunshine Coast Express, Tame Times, The Citizen, The Gremlin, The Mercury, The Newspaper, The SA News, The Star, The Tembisan, The White River Post, The Witness, Tygerburger, UD News, Uitenhage Despatch, Ulundi Fever, Upper Coast Fever, Uvo Lwethu Express, VaalWeekblad, Vista News, Vryheid Herald, Vrystaat News, Weslander, West Side Urban, Worcester Standard, Zola Urban News, Zululand Fever, Zululand Observer 


\section{Text Pre-Processing}

Because we have a multilingual corpus, as a first step, we use Microsoft Azure's Translator Text API to translate all isiZulu and Afrikaans stories into English. Denny and Spirling (2018) discuss pre-processing steps political scientists have employed for unsupervised models. We use a set of machine learning pipeline techniques not generally employed in the political science literature for our pre-processing. Rather than stemming text, we use a machine learning tokenizer. Then, we tag part-of-speech (POS), use named entity recognition, and parse dependencies (e.g., direct object, nominal subject, expletive etc.). All numeric (percent, ordinal, cardinal, money) and time (date, time) named entity tokens are replaced with the entity name, ${ }^{1}$ and remaining entity tokens (people, organizations, places) are lower-cased and concatenated with "ENT" (short for entity). Other non-entity tokens are lemmatized and concatenated with the POS-type. Since we have POS tags for the corpus, we filter tokens by their POS tags, keeping all named entities and content-words (adjectives, adverbs, nouns, proper nouns, and verbs). We drop all words appearing in fewer than 10 documents, or words appearing in more than $90 \%$ of the documents. After pre-processing, the corpus used in estimating the topic model has a vocabulary of 39,205 words and 97,350 documents with 16,609,405 (an average of 171).

We employ an NLP pipeline because we are interested in recognizing named entities. Modern NLP software makes this feasible, and so we base our decision on our theoretical interest in these named entities, which avoids some (though of course not all) ambiguation issues (e.g. "democratic", "national", "freedom" are all words but also comprise part of the names of political parties) and is also more directly interpretable. For example, allowing for named entity recognition makes the two distinct bi-grams of "Jacob Zuma" and "President Zuma" and the unigram "Zuma," which would yield three different attributes without named entity recognition, one attribute using named entity recognition. We note that we do not directly drop stop words in this pipeline, and recent work has shown that this step does not generally improve the quality of topics (Schofield et al., 2017)

\footnotetext{
${ }^{1}$ For example, the date token "May 7th, 2018" is replaced by "-DATE-" and '5\%' by "-PERCENT-".
} 


\section{E All Topics in Corpus}

\begin{tabular}{|c|c|}
\hline Topic & Labels \\
\hline 1 & $\begin{array}{l}\text { ml|NOUN cheese|NOUN onion|NOUN sauce|NOUN flour|NOUN tomato|NOUN } \\
\text { pizza|NOUN herb|NOUN lemon|NOUN bake|VERB }\end{array}$ \\
\hline 2 & $\begin{array}{l}\text { affidavit|NOUN sequestration|NOUN mona|ENT sassa|ENT asa|ENT mdluli|ENT } \\
\text { blower|NOUN summon|NOUN npa|ENT disciplinary|ADJ }\end{array}$ \\
\hline 3 & $\begin{array}{l}\text { ifp } \mid \text { ENT } \quad \text { national_freedom_party } \mid \text { ENT } \\
\text { pan_africanist_congress } \mid \text { ENT kasrils } \mid \text { ENT caucus } \mid \text { NOUN ramphele } \mid \text { ENT cope } \mid \text { ENT } \\
\text { ronnie_kasrils } \mid \text { ENT counting } \mid \text { NOUN }\end{array}$ \\
\hline 4 & $\begin{array}{l}\text { jesus|ENT zoo|NOUN cholesterol|NOUN temple|NOUN resurrection|NOUN je- } \\
\text { sus_christ|ENT disciple|NOUN obese|ADJ lego|ENT apnea|NOUN }\end{array}$ \\
\hline 5 & $\begin{array}{l}\text { madonsela|ENT morsi|ENT sisi|ENT kraal|NOUN modi|ENT hoc|NOUN } \\
\text { impeachment|NOUN bjp|ENT derby-lewis|ENT brotherhood|ENT }\end{array}$ \\
\hline 6 & $\begin{array}{l}\text { advert|NOUN south_african_broadcasting_corporation|ENT tlakula|ENT inde- } \\
\text { pendent_communications_authority_of_south_africa|ENT poster|NOUN icasa|ENT } \\
\text { julius_malema|ENT dewani|ENT t|NOUN economic_freedom_fighters|ENT }\end{array}$ \\
\hline 7 & $\begin{array}{l}\text { johannesburg_roads_agency|ENT pothole|NOUN ratepayer|NOUN tenant|NOUN } \\
\text { refuse|NOUN vagrant|NOUN } \\
\begin{array}{l}\text { oral_committee|ENT moqhaka|ENT } \\
\text { oflaw|NOUN }\end{array}\end{array}$ \\
\hline 8 & $\begin{array}{l}\text { boko_haram|ENT islamic|ENT muslim|ENT guinea|ENT } \\
\text { chibok|ENT islamist|ENT erdogan|ENT abuja|ENT mali|ENT }\end{array}$ \\
\hline 9 & 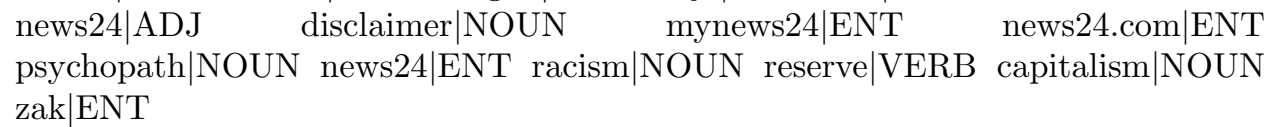 \\
\hline 10 & $\begin{array}{l}\text { astrazeneca|ENT broadband|NOUN telescope|NOUN locomotive|NOUN } \\
\text { transnet|ENT wi-fi|ENT cell_c|ENT nef|ENT prasa|ENT metrorail|ENT }\end{array}$ \\
\hline 11 & $\begin{array}{l}\text { rhino|NOUN |NOUN |VERB cms_bookmaker_bet365.gr|ENT poacher|NOUN } \\
\text { angler|NOUN _click|ENT poach|VERB afri_dome|ENT rhinos|NOUN }\end{array}$ \\
\hline 12 & $\begin{array}{l}\text { pajero|ENT turbo|NOUN almera|ENT rear|ADJ steering|NOUN suv|NOUN } \\
\text { corolla|ENT torque|NOUN airbag|NOUN alloy|NOUN }\end{array}$ \\
\hline 13 & 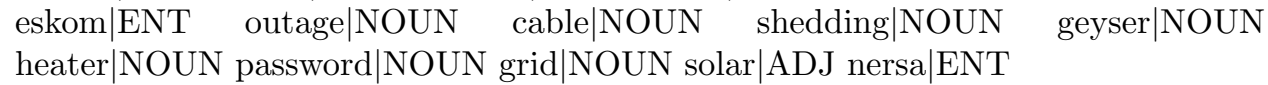 \\
\hline 14 & $\begin{array}{l}\text { sapa|VERB email|NOUN yemen|ENT username|NOUN url|NOUN 24.com|ENT } \\
\text { elections.org.za|URL korkie|ENT tb|ENT meadowlands|ENT }\end{array}$ \\
\hline 15 & $\begin{array}{l}\text { agriculture|NOUN ndp|ENT abject|ADJ gordhan|ENT inequality|NOUN } \\
\text { wing|VERB nene|ENT disadvantage|VERB udm.org.za|URL nhlanhla_nene|ENT }\end{array}$ \\
\hline 16 & $\begin{array}{l}\text { bruce|ENT van_gaal|ENT bouteflika|ENT bcci|ENT noah|ENT mandla|ENT } \\
\text { srinivasan|ENT tsarnaev|ENT anni|ENT nelson_mandela_children's_hospital|ENT }\end{array}$ \\
\hline
\end{tabular}

Table E.5: Topics 1-16 from the 32-topic model labelled with the 10 words having the highest FREX score (Bischof and Airoldi, 2012). 


\begin{tabular}{|c|c|}
\hline Topic & \\
\hline 17 & apprehend|VERB \\
\hline & $\begin{array}{l}\text { inquest|NOUN detective|NOUN rob|VERB bakkie|NOUN paramedic|NOUN } \\
\text { housebreaking|NOUN }\end{array}$ \\
\hline 18 & edal|NOUN hockey|NOUN boxing|NOUN athletic|NOUN netball|NOUN \\
\hline 19 & $\begin{array}{l}\text { bronze|NOUN box|VERB championship|NOUN relay|NOUN paddler|NOUN } \\
\text { amcu|ENT lonmin|ENT vavi|ENT miner|NOUN num|ENT smiley|ENT na- } \\
\text { tional_union_of_metalworkers_south_africa|ENT palestinian|ENT palestinians|ENT } \\
\text { anglo_american_platinum|ENT }\end{array}$ \\
\hline 20 & $\begin{array}{l}\text { oscar_pistorius|ENT } \quad \text { nel|ENT } \\
\text { reeva_steenkamp|ENT krejcir|ENT } \\
\text { gerrie_nel|ENT dixon|ENT lukhele|ENT }\end{array}$ \\
\hline 21 & $\begin{array}{l}\text { UN currency|NOUN bloomberg|ENT yield|NOUN lending|NOUN } \\
\text { UN economist|NOUN ounce|NOUN alibaba|ENT inflation|NOUN }\end{array}$ \\
\hline 22 & $\begin{array}{l}\text { pope|NOUN rea_vaya|ENT instagram|ENT xinjiang|ENT francis|ENT } \\
\text { beyonce|ENT kanye|ENT mars|ENT clinton|ENT kim_kardashian|ENT }\end{array}$ \\
\hline 23 & $\begin{array}{lccr}\text { voting|NOUN } & \text { id|NOUN } & \text { department_of_home_affairs|ENT } \\
\text { station|NOUN } & \text { voter|NOUN } & \text { register|VERB } & \text { indepen- } \\
\text { dent_electoral_commission_of_south_africa|ENT } & \text { vote|VERB } & \text { registration|NOUN } \\
\text { vote|NOUN } & & \end{array}$ \\
\hline 24 & $\begin{array}{l}\text { indian_ocean|ENT kuala_lum } \\
\text { diver|NOUN malaysia_airline }\end{array}$ \\
\hline 25 & $\begin{array}{ll}\text { vaal_weekly|ENT puppy|NOUN auntie|ENT greeting|NOUN } & \text { ed|ENT } \\
\text { python|NOUN marie|ENT emma|ENT vdbp|ENT kitten|NOUN } & \end{array}$ \\
\hline 26 & 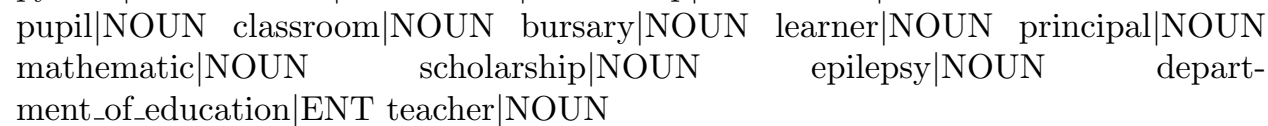 \\
\hline 27 & $\begin{array}{l}\text { lone|NOUN apple|ENT google|ENT software|NOUN } \\
\mathrm{ft} \mid \text { ENT apps|NOUN android|ENT patent|NOUN }\end{array}$ \\
\hline 28 & $\begin{array}{l}\text { t|NOUN cheetahs } \mid \text { ENT sharks } \mid \text { ENT } \\
\text { TT chelsea|ENT united|ENT }\end{array}$ \\
\hline 29 & $\begin{array}{l}\text { N nkosi|ENT smal|ENT edenvale|ENT } \quad \text { sanbs|ENT cansa|ENT } \\
\text { N melanoma|NOUN kansa|ENT pet|NOUN }\end{array}$ \\
\hline 30 & $\begin{array}{l}\text { JN computicket|ENT guitar|NOUN } \\
\text { N musical|ADJ album|NOUN }\end{array}$ \\
\hline 31 & 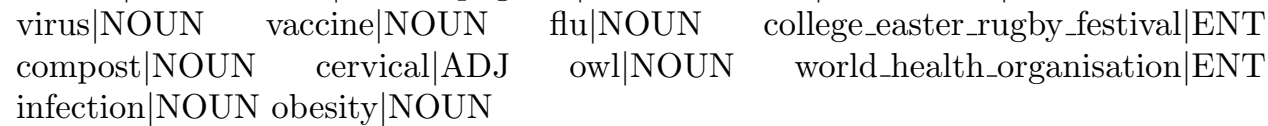 \\
\hline 32 & $\begin{array}{l}\text { NT moscow|ENT kiev|ENT crimea|ENT } \\
\text { kremlin|ENT }\end{array}$ \\
\hline
\end{tabular}

Table E.6: Topics 17-32 from the 32-topic model labelled with the 10 words having the highest FREX score (Bischof and Airoldi, 2012). 


\section{F Timing Figures}

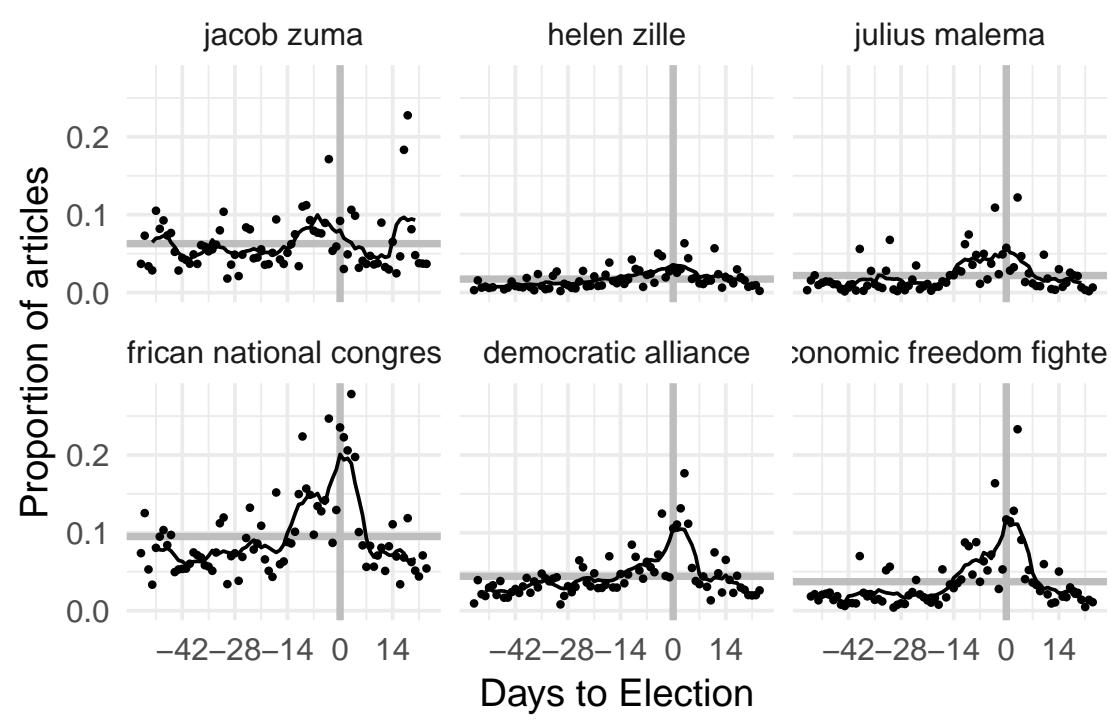

Figure F.4: Proportion of articles containing at least one mention of the three largest parties and their candidates ("African National Congress" \& Jacob Zuma, "Democratic Alliance" \& Helen Zille, and "Economic Freedom Fighters" \& Julius Malema). Dots are daily values and lines are seven-day centered moving averages of the proportion of articles containing at least one mention of the terms. The horizontal line is the average daily proportion of the term. The x-axis is 42 days (6 weeks) before the election through 14 days (2 weeks) after. The vertical line is election day

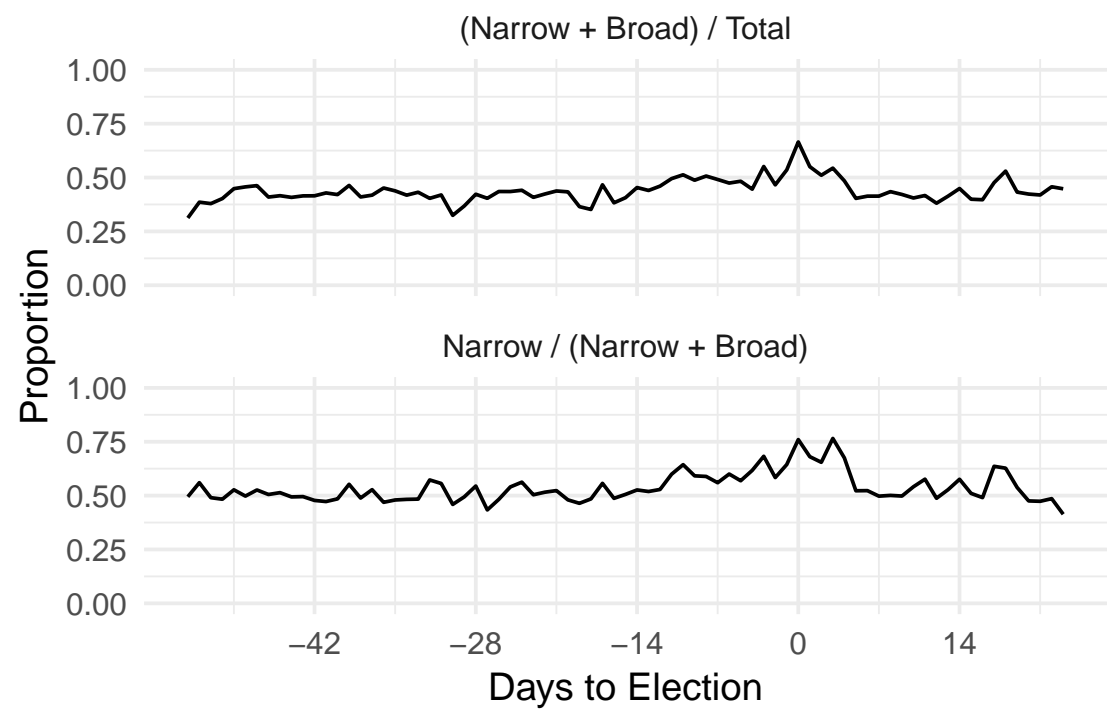

Figure F.5: Proportion of articles in the Narrow, Broad, and Non-election categories by day. 


\section{A By Language}

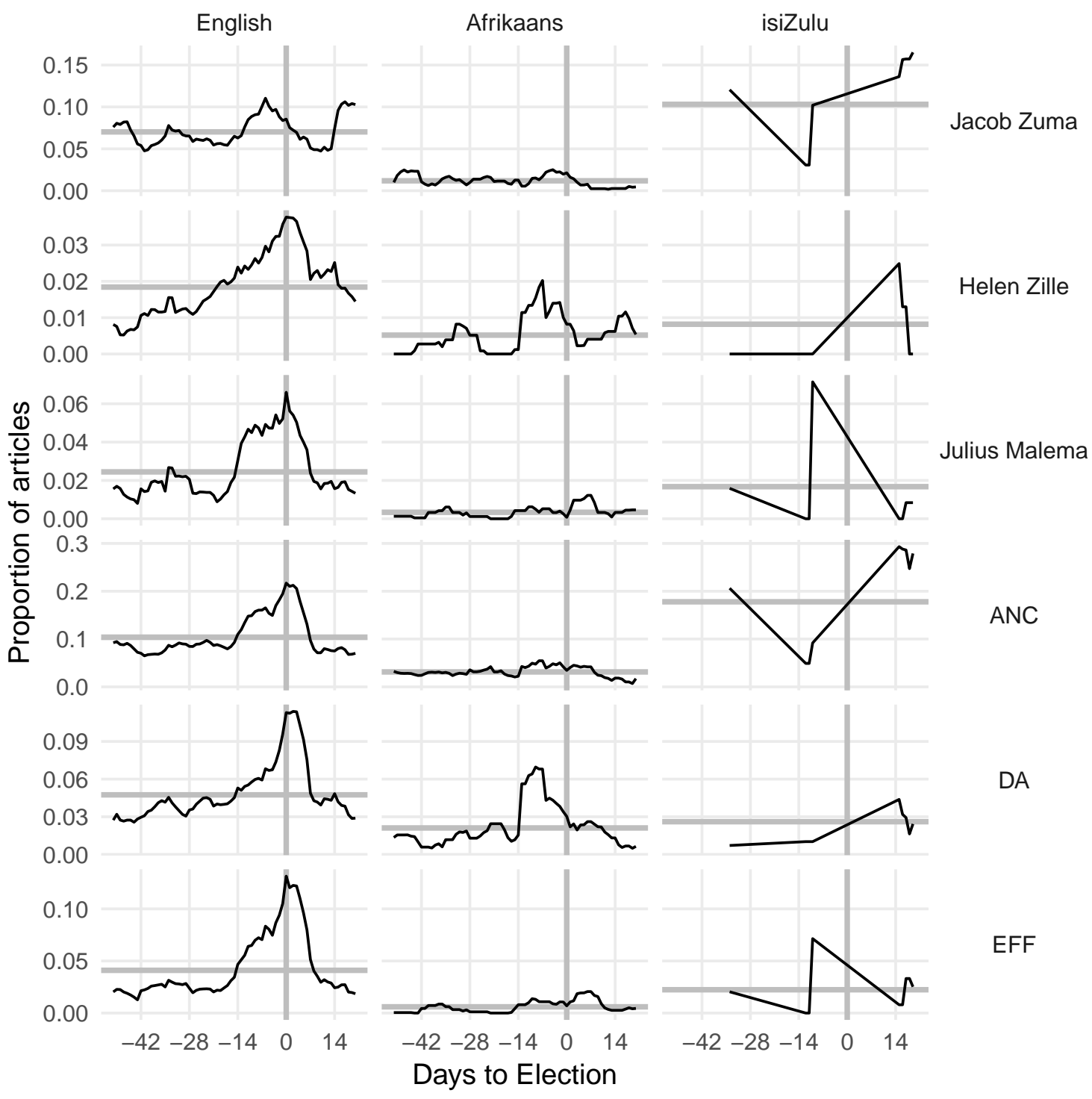

Figure F.6: Proportion of articles by each major language (English, Afrikaans, isiZulu) containing at least one mention of the three largest parties and their candidates ("African National Congress" \& Jacob Zuma, "Democratic Alliance" \& Helen Zille, and "Economic Freedom Fighters" \& Julius Malema). Dots are daily values and lines are seven-day centered moving averages of the proportion of articles containing at least one mention of the terms. The horizontal line is the average daily proportion of the term. The x-axis is 42 days (6 weeks) before the election through 14 days (2 weeks) after 


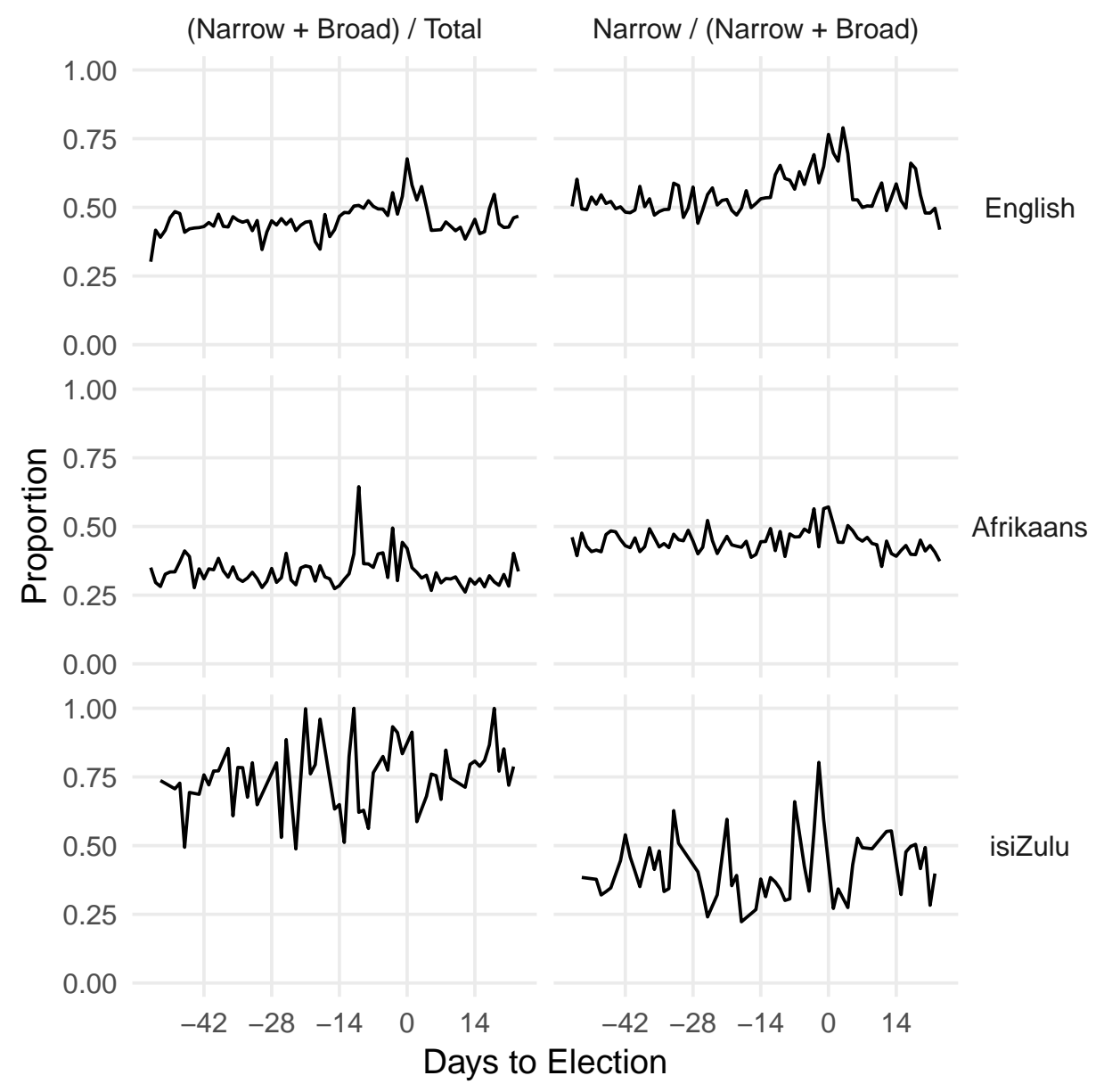

Figure F.7: Proportion of articles in the Narrow, Broad, and Non-election categories for each language (English, Afrikaans, isiZulu) by day. 


\section{G Word Vectors}

Word vectors are a neural network approach used to capture relationships between words. Indeed, it has been shown in a variety of contexts that the word2vec architecture can find the similarity between words. ${ }^{2}$ We, therefore, use word vectors to extract similarities between words that were found to be important and related to the South African election campaigns, political parties, and political figures.

\section{A Technicalities of the Word2Vec implementation}

Word vectors capitalize a trick from machine learning in which researchers employ neural networks to learn weights on the hidden layer of the network. Another version of word2vec, doc2vec (Le and Mikolov, 2014), is an abstraction of word2vec, where a feature for each document is also used in training the model.

We use the skip-gram negative sample implementation of both word2vec and doc2vec implemented in the gensim package in Python. The skip-gram implementation of the algorithm is seen as better when dealing with infrequent words. The skip-gram implementation of word2vec also requires the specification of a window size (within how many words a word will co-occur). We use a window-size of ten for all of the models.

With the word vector approach we can interpret our output as the probability for every word in our vocabulary of being near our word of interest. We run eight different versions, four in word2vec and four using doc2vec. For both word2vec and doc2vec, we run a time-varying and a non-timevarying version of the model. In the time-varying version of the model, words are binned into weeks. We show the parameters of these different models in Table G.7.

\footnotetext{
${ }^{2}$ An example using the press in the United States can be found: https://www.propublica.org/article/ breaking-the-black-box-how-machines-learn-to-be-racist?word=Clinton
} 


\begin{tabular}{lllr}
\hline Models & Type & Time Variant & Words \\
\hline model 1 & Word2Vec & No & 1,000 \\
model 2 & Word2Vec & Yes & 1,000 \\
model 3 & Doc2Vec & No & 1,000 \\
model 4 & Doc2Vec & Yes & 1,000 \\
model 5 & Word2Vec & No & 3,000 \\
model 6 & Word2Vec & Yes & 3,000 \\
model 7 & Doc2Vec & No & 3,000 \\
model 8 & Doc2Vec & Yes & 3,000 \\
\hline
\end{tabular}

Table G.7: Table of word2vec and doc2vec models run and the various parameters set.

In order to validate the approach and determine the best model, we set up a validation task. We rate each model on its ability to match 10 political leaders and 10 parties. That is, each political leader should have the highest cosine similarity with the party he or she is a leader of and vice-versa. We show in Table G. 8 that Model 1, the word2vec model, with 1,000 words outperforms the other seven models on our task where it correctly matched 18 out of 20 (leaders $\rightarrow$ parties and parties $\rightarrow$ leaders) and has the highest total cosine similarity (Total score). Table G.9 shows these matches from Model 1.

\begin{tabular}{lrr}
\hline Model & Num. True & Total Score \\
\hline Model 1 & 18 & 14.90 \\
Model 3 & 14 & 11.78 \\
Model 5 & 18 & 12.34 \\
Model 7 & 16 & 9.36 \\
\hline
\end{tabular}

Table G.8: The number of correct matches of party $\rightarrow$ leader, and leader $\rightarrow$ party for 10 parties and their leaders. Column 2 shows the number of correct matches and Column 3 shows the sum for all cosine distances where the match was correct 


\begin{tabular}{|c|c|c|c|c|c|}
\hline Leader & $\begin{array}{l}\text { Clos@stos. Sim. } \\
\text { Party }\end{array}$ & Correct & Partylosest Leasder & Cos. Sim. & Correct \\
\hline jacob zuma & anc 0.71 & TRUE & anc jacob zuma & 0.71 & TRUE \\
\hline helen zille & da $\quad 0.82$ & TRUE & da helen zille & 0.82 & TRUE \\
\hline julius malema & eff $\quad 0.87$ & TRUE & eff julius malema & 0.87 & TRUE \\
\hline mamphela ramphele & agang.82 & TRUE & agangnamphela ramphele & 0.82 & TRUE \\
\hline mosiuoa lekota & cope 0.76 & TRUE & copemosiuoa lekota & 0.76 & TRUE \\
\hline pieter mulder & ffp 0.62 & TRUE & ffp pieter mulder & 0.62 & TRUE \\
\hline mangosuthu buthelezi & cope 0.70 & FALSE & ifp mangosuthu buthelezi & 0.67 & TRUE \\
\hline bantu holomisa & $\mathrm{udm} 0.73$ & TRUE & udmbantu holomisa & 0.73 & TRUE \\
\hline kenneth meshoe & $\operatorname{acdp} 0.70$ & TRUE & acdpbantu holomisa & 0.70 & FALSE \\
\hline zanele kamagwaza-msibi & nfp $\quad 0.72$ & TRUE & nfp zanele kamagwaza-msibi & 0.72 & TRUE \\
\hline
\end{tabular}

Table G.9: Matches from Model 1 


\section{H South African ICT environment}

South Africa has enjoyed rapid growth of ICT in recent years. It boasts the highest cellular phone connections per capita in Africa, ${ }^{3}$ and the fifth highest internet access rate. Cell phone saturation was almost $90 \%$ in the 2011 census and has since risen to almost 100\%. Web-enabled feature phones and smartphones currently have a saturation rate of $70 \%$. More economically developed areas of South Africa have higher usage rates, as do younger and more male populations. This would provide citizens with the tools to more easily access published news and social media, including from the campaign.

\section{Appendix References}

Angelopulo, George and Petrus Potgieter (2016). Media Ownership and Concentration in South Africa - Oxford Scholarship. In E. M. Noam (Ed.), Who Owns the World's Media?: Media Concentration and Ownership around the World, pp. 987-1014. Oxford U. P.

Davenport, Christian and Will H. Moore (2015). Conflict Consortium Standards \& Best Practices for Observational Data. Working Paper.

Denny, Matthew J. and Arthur Spirling (2018). Text Preprocessing For Unsupervised Learning: Why It Matters, When It Misleads, And What To Do About It. Political Analysis 26(2), 168-189.

Holmes, Carolyn E. (2015). Marikana in Translation: Print Nationalism in South Africa's Multilingual Press. African Affairs 114(455), 271-294.

Le, Quoc V. and Tomas Mikolov (2014, May). Distributed Representations of Sentences and Documents. arXiv:1405.4053 [cs]. arXiv: 1405.4053.

\footnotetext{
${ }^{3}$ As of 2014, 149 connections per 100 citizens; Nigeria has 77.84 per 100 (World Bank, 2014).
} 
Ndlovu, Musa (2011, August). The meaning of post-apartheid Zulu media. Communicatio 37(2), 268-290.

Reeves, Andrew , Stephen Shellman, and Brandon Stewart (2006). Fair \& balanced or fit to print? The effects of media sources on statistical inferences. Working Paper.

Schofield, Alexandra, Måns Magnusson, and David Mimno (2017, April). Pulling Out the Stops: Rethinking Stopword Removal for Topic Models. In Proceedings of the 15th Conference of the European Chapter of the Association for Computational Linguistics: Volume 2, Short Papers, Valencia, Spain, pp. 432-436. Association for Computational Linguistics.

World Bank (2014). Mobile cellular subscriptions. data retrieved from World Development Indicators, http://data.worldbank.org/indicator/IT.CEL.SETS.P2. 